\title{
Solomon Islands: 2008 Article IV Consultation-Staff Report; Staff Supplement; Public Information Notice on the Executive Board Discussion
}

Under Article IV of the IMF's Articles of Agreement, the IMF holds bilateral discussions with members, usually every year. In the context of the 2008 Article IV consultation with Solomon Islands, the following documents have been released and are included in this package:

- The staff report for the 2008 Article IV consultation, prepared by a staff team of the IMF, following discussions that ended on July 25, 2008, with the officials of Solomon Islands on economic developments and policies. Based on information available at the time of these discussions, the staff report was completed on September 10, 2008. The views expressed in the staff report are those of the staff team and do not necessarily reflect the views of the Executive Board of the IMF.

- $\quad$ A supplement on the joint IMF/World Bank debt sustainability analysis.

- $\quad$ A Public Information Notice (PIN) summarizing the views of the Executive Board as expressed during its October 20, 2008 discussion of the staff report that concluded the Article IV consultation.

The document listed below has been or will be separately released.

Tax Summary and Statistical Appendix Paper

The policy of publication of staff reports and other documents allows for the deletion of market-sensitive information.

Copies of this report are available to the public from

International Monetary Fund $\bullet$ Publication Services

$70019^{\text {th }}$ Street, N.W. $\bullet$ Washington, D.C. 20431

Telephone: (202) 623-7430 • Telefax: (202) 623-7201

E-mail: publications@imf.org • Internet: http://www.imf.org

Price: $\$ 18.00$ a copy

\section{International Monetary Fund}

Washington, D.C. 

INTERNATIONAL MONETARY FUND

SOLOMON ISLANDS

\author{
Staff Report for the 2008 Article IV Consultation \\ Prepared by the Staff Representatives for the 2008 Consultation \\ with Solomon Islands \\ Approved by Kalpana Kochhar and Martin Fetherston
}

September 10, 2008

Discussions: Held in Honiara, Solomon Islands, July 16-25, 2008. The mission met with the Minister of Finance, Governor of the Central Bank, other ministries and government agencies, public enterprises, the business community, and donors.

Team: Ms. Thacker (Head), Ms. Fernandez, and Mr. Vitek (all APD). Mr. Moveni (OED) joined some of the meetings.

Past Fund Advice: Executive Directors' comments at the conclusion of the last Article IV consultation on July 16, 2007, can be found at http://www.imf.org/external/np/sec/pn/2007/pn07110.htm.

The effectiveness of past surveillance remains mixed (see Annex I, Informational Annex).

Exchange Arrangement: The Solomon Islands accepted the obligations of Article VIII, Sections 2(a), 3, and 4 in 1979 and maintains an exchange system that is free of restrictions on payments and transfers for current international transactions. The exchange rate regime is a de facto peg to the U.S. dollar.

Outreach: The mission met with donors.

Publication: The mission encouraged the authorities to publish the Article IV documents as they have done in previous years.

Statistics: Despite some improvements, the coverage and quality of data remain poor, partly reflecting capacity constraints, and hamper effective surveillance. 


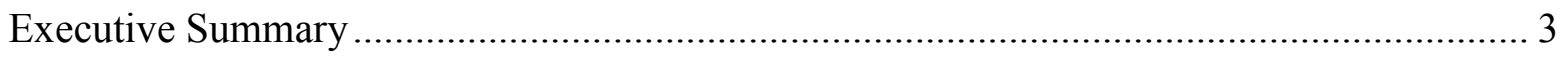

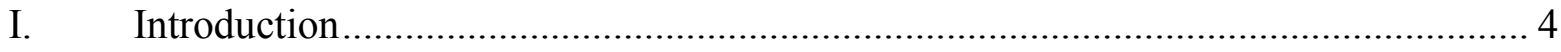

II. Recent Developments and the Near-term Outlook ................................................... 4

III. Medium-term Macroeconomic Outlook and Risks................................................... 6

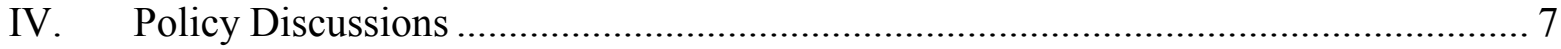

A. Macroeconomic Policies to Contain Inflation.................................................... 8

B. Addressing Medium-term Fiscal and External Sustainability ................................ 9

C. Stimulating Nonlogging Sector Growth............................................................... 11

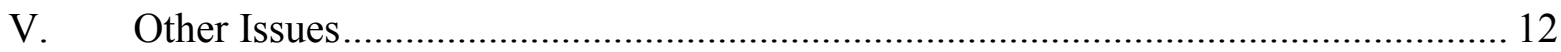

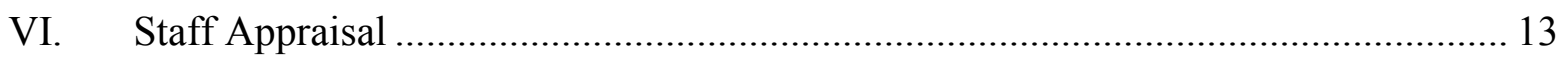

Boxes

1. Recent Inflation Developments in the Solomon Islands ........................................ 15

2. An Exchange Rate Assessment for the Solomon Islands ……………................... 16

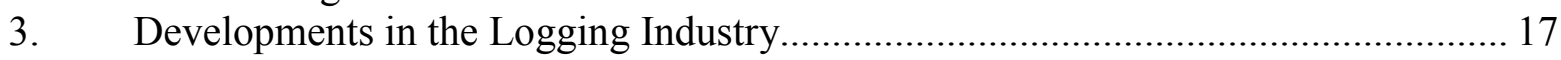

Figures

1. Graphical Summary of Recent Macroeconomic Developments................................ 18

2. Projections of Key Macroeconomic Variables Under Baseline and Alternative

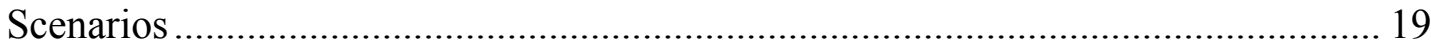

\section{Tables}

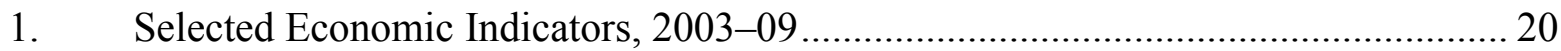

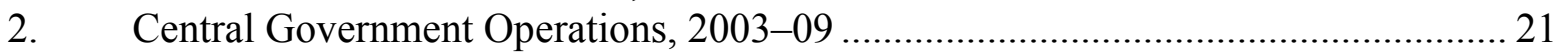

3. Summary Accounts of the Banking System, 2003-08 ……………………......... 22

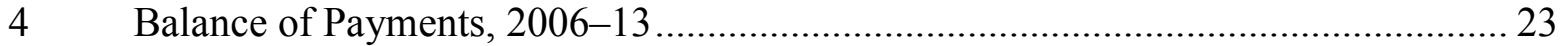

5. Indicators of External Vulnerability, 2003-09 ……………………………........... 24

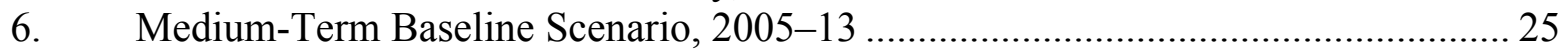




\section{EXECUTIVE SUMMARY}

\section{Background and Challenges}

Economic performance remains strong, but inflation has increased. Real GDP grew by 10.3 percent last year. For 2008, real GDP growth is projected at 71/4 percent, reflecting a continued rise in unsustainable logging activity, and strong growth in nonlogging sectors. Inflation has picked up recently due to increases in international food and fuel prices and loose domestic policies. The fiscal deficit is expected to widen significantly, reflecting the approval of a large supplementary budget in August. The current account deficit is also expected to widen due to higher food and fuel imports, and mining-related FDI. Reserves are expected to remain at 3 months of projected imports.

Over the medium term, logging and aid inflows are expected to fall sharply, negatively impacting growth, and the balance of payments and fiscal positions. Exports from the gold mine, scheduled to start operation in 2010, will offset the decline in reserves, but the budget will be strained, requiring significant efforts to boost revenues and cut expenditures.

\section{Key Policy Issues and Recommendations}

\section{Against this background, the mission focused on three key policy issues:}

- Tightening monetary and fiscal policies to contain inflation. The authorities have responded to higher inflation by tightening credit conditions and removing taxes on rice. However, monetary and fiscal policies need to be tightened further to prevent inflation from becoming entrenched. The mission recommended raising the liquid asset requirement (LAR) and restraining fiscal spending. The authorities agreed with the need for additional monetary tightening, but argued that political and economic constraints prevent a reduction in fiscal spending.

- Safeguarding fiscal and external sustainability over the medium term as logging activity declines. On the fiscal front, urgent measures are needed to strengthen the mediumterm fiscal framework, pursue reform measures to boost revenues, and accelerate the restructuring of loss-making state-owned enterprises. On the external front, export diversification is critical to replace declining logging export receipts. Impediments to the operation of the gold mine need to be urgently addressed, including the resolution of land ownership issues. The mission also encouraged the authorities to permit greater exchange rate flexibility to safeguard reserves.

- Stimulating nonlogging sector growth. Progress on structural reforms remains slow. The authorities' medium-term strategy focuses on fostering competition, improving the provision of basic services, upgrading infrastructure, and addressing land ownership issues. 


\section{INTRODUCTION}

1. The political situation in the Solomon Islands (SI) has been generally stable since 2003, but remains fragile. The Regional Assistance Mission to the Solomon Islands (RAMSI) has helped to maintain peace and order since 2003, focusing on strengthening the country's institutional capacity and preventing future conflict. However, a recent study argues that long-term peace-building requires a clearer understanding of the causes and dynamics of conflict. ${ }^{1}$ The government has taken serious steps in this direction through examining the root causes of the ethnic tensions and is preparing a Political Integrity Bill to enhance political stability.

\section{Despite rapid growth during the last} five years, the SI ranked the poorest among the Pacific Island countries in 2007. Real GDP growth averaged 7 percent during the last five years, driven by unsustainable logging sector activity and aid inflows. However, progress towards achieving the Millennium Development Goals remains slow and per capita income remains below its pre-conflict level (see Informational Annex).

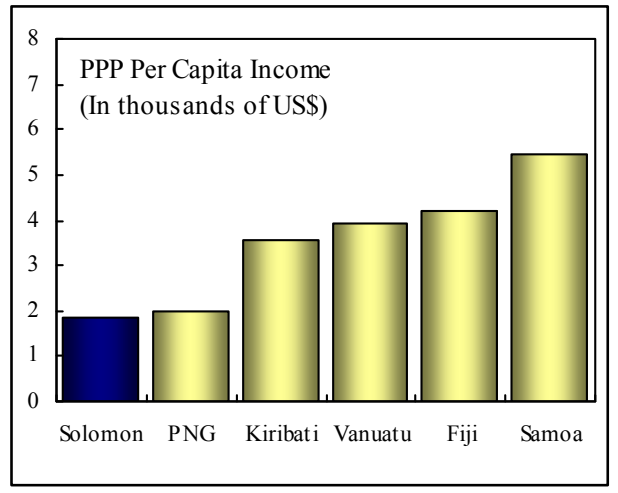

\section{RECENT DEVELOPMENTS AND THE NEAR-TERM OUTLOOK}

\section{Real GDP growth increased to $\mathbf{1 0 . 3}$ percent}

last year, driven by the logging and services sectors (Table 1). Preliminary figures for the first half of 2008 suggest continued strong growth in these sectors, while other sectors, most notably palm oil production and fisheries, have also picked up. Real GDP is projected to increase by over 7 percent in 2008.

\section{The rapid increase in international commodity prices has fueled inflationary} pressures. Headline inflation increased to over 16 percent (3-month moving average) at end-June

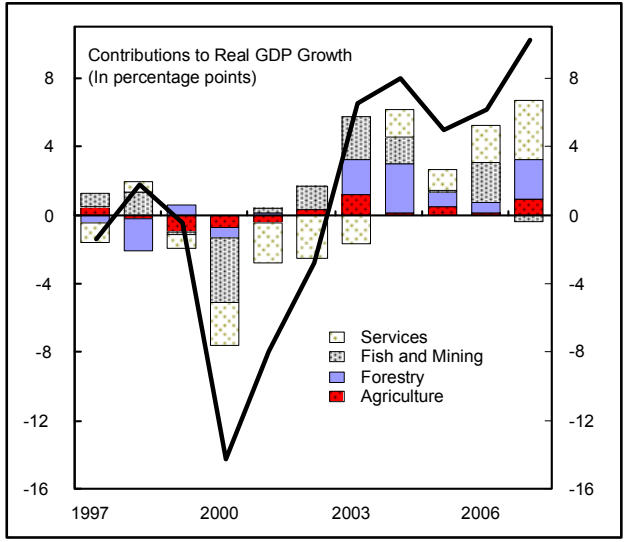
2008 from 10 percent at end-2007, and core inflation is up 14 percent during this period (Box 1). At the same time, rapid private sector credit growth since 2004, an expansionary fiscal stance since last year and the gradual depreciation of the SI dollar in nominal effective terms have also been important contributory factors. As food and fuel prices stabilize and recent monetary measures to tighten excess liquidity gain traction (see below), headline inflation is projected to decline somewhat and end the year at about 15 percent (year-onyear).

${ }^{1}$ Hameiri, Shahar (2007), "The Trouble with RAMSI: Reexamining the Roots of Conflict in the Solomon Islands." 
5. Fiscal policy continues to be expansionary. Despite significant revenue overperformance last year, the fiscal balance swung to a deficit of 1.5 percent of GDP from a surplus of 1.7 percent of GDP in 2006 (Table 2). Most of the increased spending was on recurrent items - wages, and goods and services. On a cyclically-adjusted basis, the fiscal deficit in 2007 was even more expansionary. Preliminary data for the first half of 2008 suggest that spending continues to exceed revenues. In addition, the

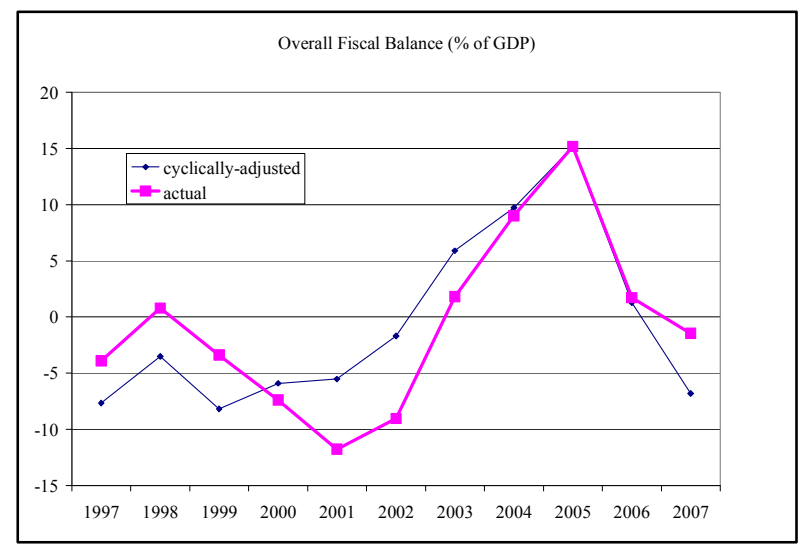
government has approved a supplementary budget, estimated at an unprecedented $51 / 2$ percent of GDP, with 21/2 percent to meet payroll increases granted in May. However, the bulk of the financing for new spending has yet to be identified.

\section{Excess liquidity at commercial} banks has declined. Private sector credit increased at an annual rate of about 60 percent during the last three years, albeit from a low base, with personal loans rising the fastest (Table 3). In order to reduce excess liquidity and commercial bank lending, the CBSI has allowed the National Provident Fund (NPF) to invest abroad up to 30 percent of its investment portfolio (about US\$20 million) and introduced standing deposit facilities in July. As a result, bank lending has slowed recently.

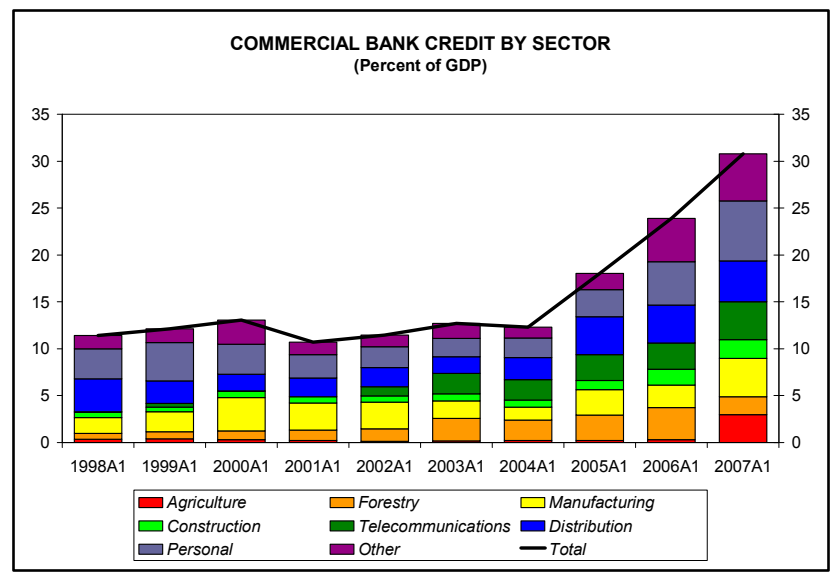

7. Reserves remain adequate, but the deterioration in the terms of trade is expected to widen the current account deficit. A pickup in logging exports (both volume and price effects) and aid inflows, together with higher FDI, more than offset the increase in the food and fuel import bill last year (Table 4). As a result, official international reserves increased by US\$16 million to US\$120 million (about 4 months of projected imports). However, reserves have declined more recently due to debt repayments, NPF investments abroad, and higher imports. The current account deficit is projected to widen to 7 percent of GDP in 2008, financed largely by aid inflows and mining-related FDI. Reserves are expected to remain at about 3 months of projected imports during the remainder of the year.

8. The SI dollar depreciated by 9 percent in nominal effective terms during the year to end-May 2008, reflecting its de facto peg to the U.S. dollar (Box 2). However, it remained fairly stable in real effective terms, and external price competitiveness does not 
appear to be a significant concern for now. ${ }^{2}$ That said, if inflation increases further, and wage adjustments raise the cost of production, this could weaken competitiveness and reduce exports, especially those of nonlogging sectors like fisheries, palm oil, and tourism. Combined export receipts from these industries amounted to 91/2 percent of GDP in 2007.

9. The banking system remains well-capitalized and profitable. Nonperforming loans (NPLS) remain low at 3 percent (Table 5). Personal loans, the fastest growing sector, are generally collateralized by individuals' savings in the NPF and default on these loans is extremely small.

10. There has been some progress on structural reforms. The State-Owned Enterprise (SOE) Act, aimed at improving the efficiency of the SOE sector, and the Secured Transactions Act, allowing movable property to be used as collateral, were passed by parliament. The Civil Aviation and the Telecommunications Bills allowing and enhancing competition in these sectors are expected to be approved later this year. However, little progress has been made in addressing land ownership issues and easing infrastructure bottlenecks.

11. Risks to the outlook are mainly on the downside. Inflationary pressures from an excessively expansionary fiscal stance, potential demand for further wage increases, and further negative terms of trade shocks could trigger macroeconomic instability in the short run and derail the progress made recently.

\section{Medium-Term MACROECONOMIC OUTLOOK AND RISKS}

\section{The medium-term outlook hinges critically on the success of developing} nonlogging sources of growth, to offset the expected sharp decline in logging activity (Table 6). The logging sector currently accounts for 20 percent of government tax revenues and 65 percent of exports. But logging activity is expected to decline rapidly beyond 2009 and to become negligible by 2013, reflecting the unsustainably high rates of logging. Therefore, growth in other sectors, including mining (gold and nickel), palm oil production, tourism, and the services sectors, needs to be stimulated. In particular, gold mining operations, now scheduled to start in 2010, are critical to sustaining exports and foreign reserves once logging declines.

13. Risks are skewed mainly to the downside. The principal risk to external sustainability is a further delay in the start of gold mining operations which could reduce foreign exchange inflows to finance imports, resulting in a rapid depletion of reserves. Also,

\footnotetext{
${ }^{2}$ This exchange rate assessment is based on a qualitative analysis of recent and projected future balance of payments dynamics, supplemented by implementation of the equilibrium real exchange rate approach. Implementation of the macroeconomic balance and external sustainability approaches is precluded by data availability constraints.
} 
a lack of progress on structural reforms, in particular to address infrastructure bottlenecks, could slow growth significantly and lead to a decline in average income per capita.

Nevertheless, future donor aid inflows in excess of current commitments could mitigate some of these downside risks to external sustainability. The following three scenarios illustrate alternative medium-term outcomes, contingent on policy actions taken by the authorities in the coming period:

- Baseline scenario: Gold mining operations are assumed to start in 2010, as currently scheduled, but the pace of structural reforms remains moderate. While gold exports will help to offset the decline in logging export receipts, the contribution to domestic growth is expected to be limited, given the capital-intensive nature of the project and the largely unskilled local labor it will employ. As a result, the economy is expected to muddle along with an average real growth rate in the range of 3-4 percent per year, allowing for a modest increase in average per capita income over time. ${ }^{3}$

- Reform scenario: An acceleration of structural reforms could lift the economy onto a steeper growth trajectory. In particular, improvements in infrastructure and a decline in the cost of doing business could unlock the vast growth potential in the agriculture, fisheries (including canning), and tourism sectors, and expedite production in the mining sector. This would enhance fiscal and external sustainability.

- Worst-case scenario: Given the history of the Solomon Islands and the fragile nature of the coalition government, political and economic instability could resurface. If this were to occur, gold mining operations could be further delayed and other sectorsfishing, agriculture, and tourism - could lose their current growth momentum. With the rapid depletion of forests and therefore logging, this could push the economy into a protracted period of low growth with large deficits and rapidly declining reserves, necessitating difficult economic adjustments.

\section{Policy Discussions}

14. Against this background, the mission focused on the following key issues:

- Adjusting monetary and fiscal policies to contain the second-round effects on inflation from recent surges in international food and fuel prices. The authorities shared the mission's concern, but argued that recent wage increases, and the consequent rise in budget spending, was necessary to mitigate some of the impact on the poor.

\footnotetext{
${ }^{3}$ Average population growth is projected at 2.8 percent.
} 
- Safeguarding fiscal and external sustainability over the medium term as logging activity declines. The authorities agreed that timely commencement of gold mining operations was key to alleviating the pressures on the balance of payments from declining logging exports. They also recognized the need to rationalize the budget and cut spending to ensure fiscal sustainability given the current budget envelope. That said, they were hopeful that they could mobilize additional aid inflows.

- Stimulating nonlogging sector growth through infrastructure development and the resolution of land ownership issues. The authorities' medium-term development strategy focuses on these issues, and they are taking steps to allow more competition and encourage private sector growth. ${ }^{4}$

\section{A. Macroeconomic Policies to Contain Inflation}

\section{Background}

15. The increase in inflationary pressures, unless contained, could unravel the recent gains in macroeconomic stability. While most countries faced with rising international commodity prices have been tightening policies to contain inflation, expansionary monetary and fiscal policies (as discussed above) have exacerbated the second-round effects and led to additional pressure on prices.

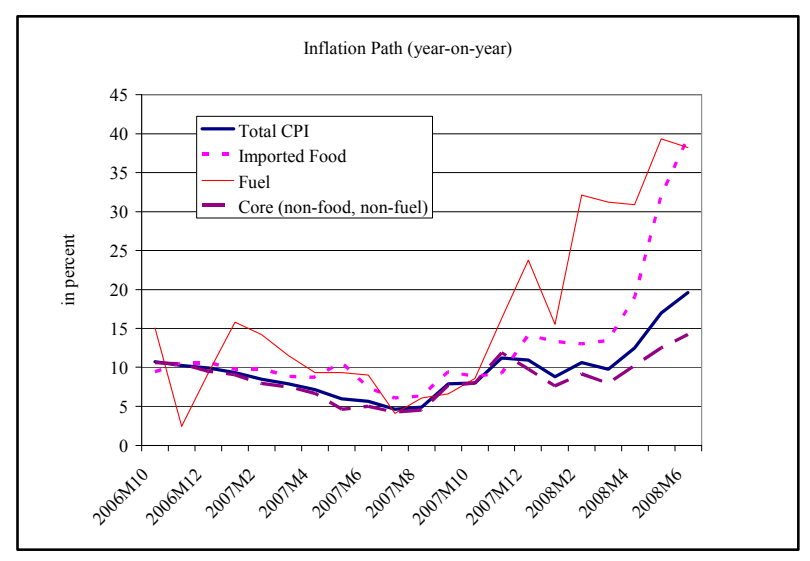

\section{Discussions}

16. The mission advised the authorities that domestic demand management policies need to be tightened to contain inflation:

- The mission discouraged the authorities from adjusting the exchange rate to counter rising inflationary pressures and instead encouraged greater exchange rate flexibility. The real effective exchange rate is broadly in line with medium-term fundamentals. With reserves falling recently due, in part, to the rising import bill, adjusting the exchange rate to counter inflation could put further pressure on reserves and jeopardize the competitiveness of nonlogging sectors like mining, fisheries, and

\footnotetext{
${ }^{4}$ The authorities presented this to donors in June. However, reception has been lukewarm with donors suggesting that the projects need to be costed and integrated within the framework of ongoing projects. Authorities are revising the document in line with these suggestions.
} 
tourism. Instead of temporarily reducing inflation by revaluing the currency, allowing for greater downward exchange rate flexibility, underpinned by appropriately tight monetary and fiscal policies, would help to safeguard reserves while containing inflation.

- On the monetary front, the authorities recognized that further tightening is needed. The authorities pointed out that recent measures (discussed above) have been effective in slowing credit growth. They concurred with staff to continue to use the standing deposit facilities, and agreed to raise the LAR if additional tightening was needed.

- $\quad$ On the fiscal front, the authorities argued that they were constrained both by economic and political realities. The authorities stressed that their initial response to inflationary pressures was to eliminate the goods tax and the import duty on rice to partially offset imported food price increases, while allowing the economy to adjust to higher fuel prices. ${ }^{5}$ However, with the continued rise in commodity prices, calls for wage increases, including most vocally by the opposition, had to be accommodated. ${ }^{6}$ That said, they argued that there will likely be some underspending in the development budget given capacity constraints.

\section{B. Addressing Medium-term Fiscal and External Sustainability}

\section{Background}

17. Debt levels have fallen, but remain significant. At end-2007, only the NPV of external debt to GDP (38 percent) breached its Board-endorsed threshold (see Debt Sustainability Analysis). All debt indicators are projected to decline and remain below their thresholds in the medium term under the baseline scenario. However, historical scenarios and several stress tests cause a number of indicators to significantly exceed their thresholds. In particular, public sector debt and external debt levels are highly sensitive to temporary declines in real GDP growth and export growth, respectively. Moreover, the medium-term outlook hinges critically on the start of gold mining operations in 2010, without which the balance of payments and foreign reserves would come under severe pressure. Based on these considerations, Solomon Islands is classified as in moderate risk of debt distress, and the

\footnotetext{
${ }^{5}$ Fuel prices are determined by private importers and retailers; however, electricity and transportation prices can be increased only after consultation with the government.

${ }^{6}$ The opposition submitted a no-confidence vote (which was defeated), citing government's lack of response to the plight of the poor due to higher food and fuel prices.
} 
government should continue its nonborrowing policy, depending solely on grants until debt sustainability risks are mitigated. ${ }^{7}$

\section{Fiscal and external sustainability could be at serious risk if gold mining is} delayed. Log exports have been very buoyant in the last five years (both due to the unsustainable rate of logging and due to higher log prices) and have nearly doubled as a share of GDP. However, instead of saving the windfall, budget spending has been increasing in line with additional revenues. With the contribution from the logging sector expected to decline sharply, gold export revenues will be instrumental in alleviating downward pressure on foreign reserves. On the other hand, fiscal sustainability will depend on cutting expenditures, unless donors provide budget support, as gold mining will contribute only marginally to improve the fiscal situation given the generous tax concessions granted to the gold mining company. The government's medium-term fiscal strategy recognizes this and envisages significant spending cuts, although it does not identify the areas where these cuts would occur.

\section{Discussions}

19. The authorities broadly agreed with the mission's recommendation on areas that could generate expenditure savings.

- Strengthen the government's medium-term fiscal framework and restructure the budget: In particular,

- Undertake civil service reforms to reduce the wage bill, including by eliminating vacant positions, and avoiding ad hoc increases in wages;

- Enhance monitoring and accountability of public enterprises to raise efficiency, and restructure those that continue to incur losses (the latter will also reduce the contingent liabilities of the government); and

- Enhance the transparency and accountability of spending by both the central government and line ministries to ensure that monies are not misspent.

- Expedite fiscal structural reforms to boost revenues: There is considerable scope for strengthening tax administration, including by reducing exemptions and enforcing tax collection, especially in the logging sector. In particular:

- Further raise the determined price of logs and introduce an automatic adjustment mechanism. ${ }^{8}$ Following strong lobbying by the logging sector,

\footnotetext{
${ }^{7}$ Thus far, the authorities have honored their commitment not to incur new borrowing. In 2008, a small amount was disbursed in relation to an existing ADB loan.

${ }^{8}$ The authorities use the determined price to calculate the tax obligation of log exporters. Adjustments to it are currently done on an ad hoc basis.
} 
the government deferred its plan to raise the determined price from June to October. Implementing this in October as planned would send a strong signal of the authorities' commitment to reforms, and would boost tax revenues (Box 3). Furthermore, saving some of this windfall to meet budgetary needs over the medium term when logging revenues decline could ease the pressure to cut spending.

Improve monitoring of the logging sector to increase tax compliance. Anecdotal evidence suggests that only 30-40 percent of log shipments are inspected, resulting in foregone tax revenues of nearly 4 percent of GDP in 2007. The mission urged the authorities to enhance monitoring by employing qualified personnel. This would not only help generate revenues that could finance much-needed social and development spending (for example, for financing free primary education or for funding more vocational training), but would also encourage sustainable logging activity.

- Accelerate SOE reforms: Following the completion of the current audit program, SOEs should be subject to regular disclosure of annual financial statements to improve financial management and restructuring. Also, divestment of enterprises that are in commercially viable sectors, for example Soltai Fishing Company and Solomon Airlines, is likely to strengthen the government's balance sheet, and should be undertaken.

20. Enhance export diversification to preserve external sustainability. External sustainability hinges on the success of offsetting the imminent decline in logging export receipts with growth in other export-oriented sectors, especially mining. The mission therefore urged the government to address bottlenecks that have repeatedly caused delays in starting gold mining operations (discussed below), while emphasizing that additional tax concessions should be avoided. Over the long term, nickel mining also has tremendous potential to generate foreign exchange receipts and boost reserves. Should ongoing exploration work establish that nickel mining is commercially viable, the mission advised the government to negotiate an equitable profit sharing agreement with assistance from qualified consultants.

\section{Stimulating Nonlogging Sector Growth}

\section{Background}

21. Progress in removing constraints to broad-based growth has been slow. Major impediments include ambiguity in land ownership, poor infrastructure, a shortage of skilled labor, and unreliable and costly electricity, water, and telecommunication services. In addition, poor governance remains widespread and the cost of doing business is relatively high by regional standards. SOEs continue to make losses and require frequent cash injections from the government. On the positive side, some progress has been made in 
improving road infrastructure with the help of the Asian Development Bank (AsDB), and in enhancing competition in the airline industry.

\section{Discussions}

22. The authorities agreed with staff and pointed to recent measures that are being taken to improve the basic institutional and infrastructure framework to stimulate nonlogging sector growth. In particular:

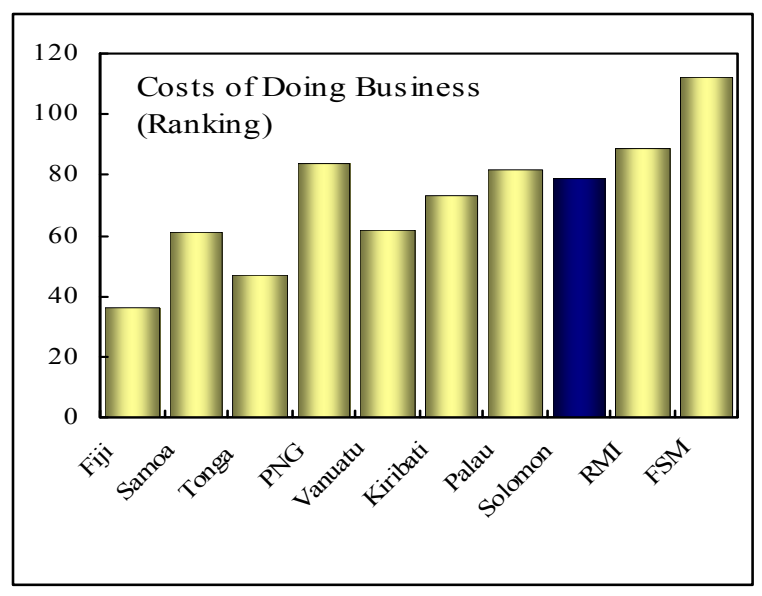

- Land ownership issues: The draft Tribal Land Bill is currently being discussed by the Ministry of Lands and the Attorney-General's office, and is expected to be tabled in the November parliamentary sitting. If passed, this law would help expedite the resolution of land ownership issues, easing access to land for commercial purposes.

- Increased competition in telecommunications: The government's agreement with Telekom, which now holds a monopoly in providing telecommunication services, is expected to be reviewed later this year to allow competition in the sector.

- Improved business environment for the private sector: The Companies Act and Insolvency Act defining the framework in which private enterprises operate will be tabled in the November parliamentary sitting.

- State-owned enterprises: External managers are being hired with the assistance of the World Bank to improve the financial viability and service delivery of the Solomon Islands Electricity Authority (the state-owned electricity company).

- Infrastructure improvements: The authorities emphasized their continued commitment to work with the AsDB to improve road and water transport and port facilities.

- Alternative sources of energy: The authorities are also exploring this area, including hydro, solar and biomass plants, with the help of the World Bank and other donors, especially as this will help to reduce their dependence on diesel imports for electricity generation.

\section{OTHER ISSUES}

23. Various financial soundness indicators reveal that commercial banks remain well capitalized and profitable. All three commercial banks are subsidiaries of foreign banks and are supervised both by the CBSI and the supervisory authorities of their parent 
banks. Most lending is collateralized and risk-weighted capital asset ratios, at about 20 percent as of March 2008, remain above the prudential norm. Moreover, nonperforming loans remain low as a share of total loans at below 3 percent. ${ }^{9}$ However, given the rapid credit growth in recent years, and the expected moderation in growth over the medium term, NPLs could rise. The CBSI agreed to continue its close monitoring of the banking sector.

24. The statistical database remains poor and hampers surveillance. Despite some improvements, the coverage and quality of the real, public, and external sectors remain deficient. Public sector statistics are inconsistent with the GFS methodology, and do not track provincial government or SOE activities. The recurrent and development budgets have yet to be integrated. External sector data suffer from serious misclassification problems. The latest Household Income and Expenditure Survey (HIES), completed in September 2006, has been used to revise the national accounts and construct GDP by expenditure component, with assistance from PFTAC. However, these have yet to be officially published.

\section{StafF ApPRAisal}

25. Political stability remains fragile. While the overall political situation has remained stable since 2003, repeated jockeying by politicians and random jumps across party lines has resulted in numerous changes in government, confounding consistent policy making. Efforts to consolidate the party system, including through the Political Integrity Bill aimed at preventing frequent party defections, are welcome, and should help create a more stable political environment.

\section{Recent growth performance has been very strong, but its sustainability is in} question. Real GDP growth reached a 15-year high last year, driven by unsustainable logging sector activity and strong service sector growth stimulated by donor aid inflows. ${ }^{10}$ More recently, some nonlogging sectors like palm oil production, fisheries, and tourism have also picked up. However, average per capita income remains below its pre-conflict level.

\section{Monetary and fiscal tightening are urgently needed to contain inflation. While} the rise in international commodity prices has been the major cause of higher inflation, expansionary domestic monetary and fiscal policies have exacerbated import price pressures as reflected in the pickup in core inflation. In this context, recent efforts by the CBSI to rein in excess liquidity through its standing deposit facilities are welcome. In order to anchor inflation expectations, the CBSI should tighten the monetary stance further, including through an increase in the LAR. To avoid placing an undue burden on monetary policy, fiscal policy also needs to play a supportive role by minimizing spending of the supplementary budget, where possible.

\footnotetext{
${ }^{9}$ Loans are classified as NPLs if they are overdue for more than 90 days.

${ }^{10}$ Aid flows are expected to decline over the medium term in line with current donor commitments.
} 
28. Maintaining fiscal sustainability will require a concerted effort to boost tax revenues and cut expenditure growth. Efforts to bolster tax revenues will need to be intensified, including by strengthening tax administration, raising the determined price of logs to reflect international market prices, and cutting ad hoc tax exemptions. In addition, reforms to rationalize civil service employment and restrain the future growth of the wage bill, enhance the monitoring of SOEs, and restructuring/privatizing loss-making ones will yield substantial savings. Improving expenditure control procedures to ensure that spending remains within budgeted levels and increasing transparency of all government accounts will also help cut expenditures.

29. Structural reforms to generate nonlogging sector growth are critical to sustain the growth momentum and preserve medium-term fiscal and external sustainability. Given the imminent decline in logging sector activity, efforts to develop alternative sources of growth should be intensified. In this context, the government's efforts to allow competition in the airlines and telecommunications industries are welcome. However, reforms to address land ownership issues, improve infrastructure, and eliminate rent-seeking activities to lower the high cost of doing business need to be implemented swiftly.

30. The real effective exchange rate appears to be broadly in line with medium-term fundamentals. However, a decline in competitiveness if inflation and wage growth are not contained, and pressure on reserves if the decline in logging exports is not offset by exports from other sectors, could necessitate exchange rate adjustment. Greater exchange rate flexibility could help avoid sudden disruptive economic adjustments.

31. The banking system remains profitable and NPLs are low, but the CBSI should continue to monitor the situation closely. While commercial banks' focus on collateralized lending combined with rapid economic growth in recent years has helped to keep NPLs low, banks remain vulnerable to a slowdown in logging sector activity. The CBSI should continue to monitor banks closely to ensure that asset quality remains sound.

32. The quality, timeliness, and availability of most data remains poor and hampers effective surveillance. Data on monetary statistics are adequate. However, data on national accounts and balance of payments, despite significant technical assistance, continue to be inadequate. Data on the provincial governments and SOEs is almost nonexistent. The authorities should give priority to improving data collection and quality, including by committing adequate resources.

33. It is recommended that the next Article IV consultation take place on the standard 12-month cycle. 


Box 1. Recent Inflation Developments in the Solomon Islands
Inflation in the Solomon Islands has
increased recently. Following a
decline from a peak of 13.1 percent in
2006Q2 to a trough of 5.8 percent in
2007Q3, annual consumption price
inflation rose to 9.7 percent in
2008Q1. This surge was primarily
attributable to an increase in import
price inflation, which rose from




\section{Box 2. An Exchange Rate Assessment for the Solomon Islands}

The Solomon Islands' dollar has experienced trend nominal depreciations with respect to the currencies of major trading partners. Since 2003, the Solomon Islands' dollar depreciated by 36 percent relative to the Australian dollar, by 21 percent relative to the Singapore dollar, and by 16 percent relative to the Chinese yuan. These developments reflect its de facto peg to the US dollar over this period.

The value of the Solomon Islands' dollar has remained broadly constant in real effective terms. During recent years, trend nominal effective depreciation has offset erosion of external price competitiveness caused by higher inflation in the Solomon Islands than among its major trading partners.
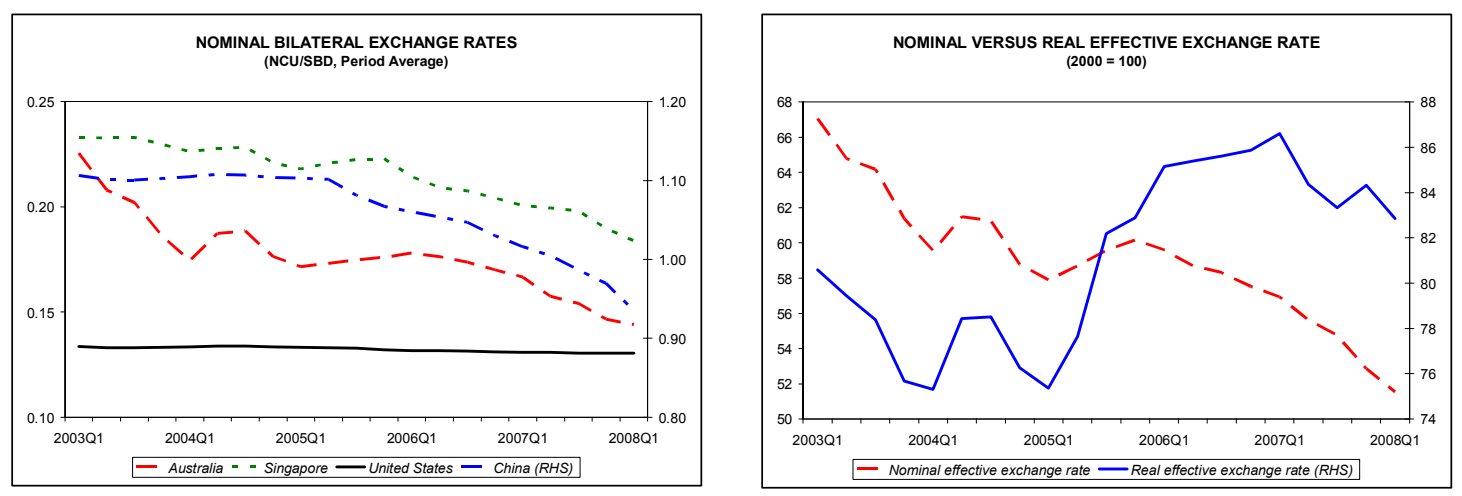

A qualitative exchange rate assessment suggests that the value of the real effective exchange rate is broadly in line with medium term fundamentals. A macroeconomic projection conditional on a constant real effective exchange rate suggests sustainable balance of payments dynamics over the medium term. However, the risks surrounding this baseline projection are tilted towards the downside. If gold mining does not begin in 2010, or if further large increases in international food and fuel prices occur, then depreciation of the currency in real effective terms may be needed to safeguard reserves following the imminent decline in logging.
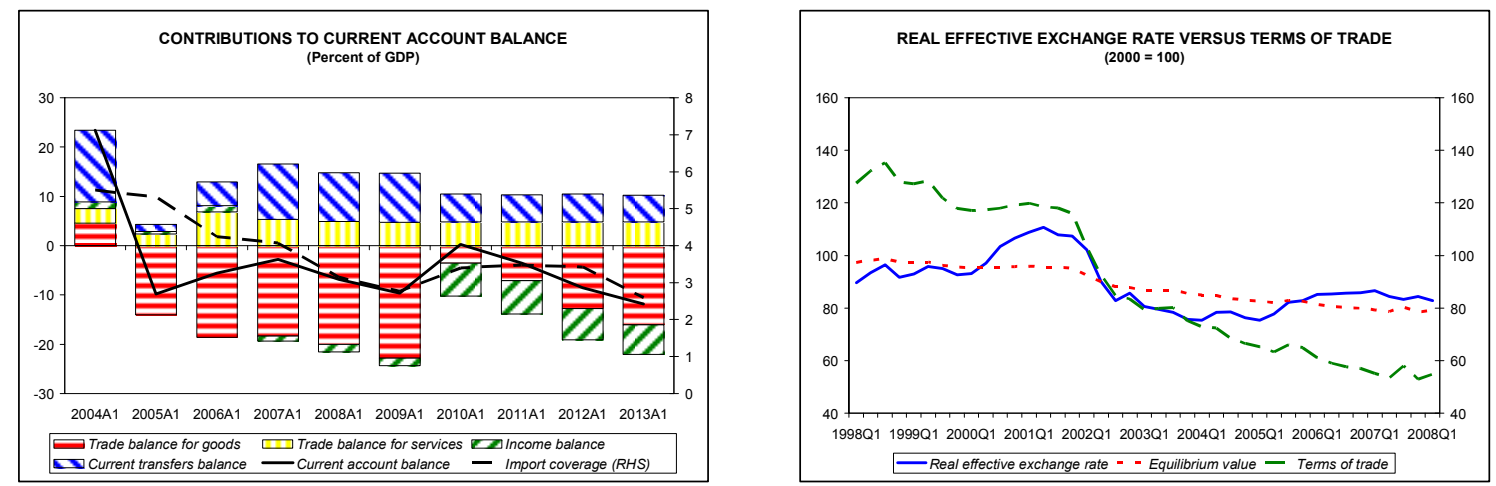

A quantitative exchange rate assessment also suggests that external price competitiveness is not a significant concern. Accounting only for trend deterioration in the terms of trade with the equilibrium real exchange rate approach suggests that the value of the real effective exchange rate is currently broadly in line with its estimated medium run equilibrium value. ${ }^{1}$ However, if further large negative terms of trade shocks occur, then depreciation of the currency in real effective terms may be needed to preserve external sustainability.

${ }^{1}$ The equilibrium real exchange rate approach yields an overvaluation estimate of 4 percent for 2008Q1. Data availability constraints preclude implementing the macroeconomic balance and external sustainability approaches. 


\section{Box 3. Developments in the Logging Industry}

Since 2003, reliance on logging has steadily increased. In 2007 , logging increased by about 25 percent and accounted for a quarter of real GDP growth, 65 percent of exports, and almost 20 percent of tax revenue. The sharp increase in logging activity was in part the result of the issuance of new licenses, re-entry into former logged areas, the approval of tree-felling operations to allow palm oil and

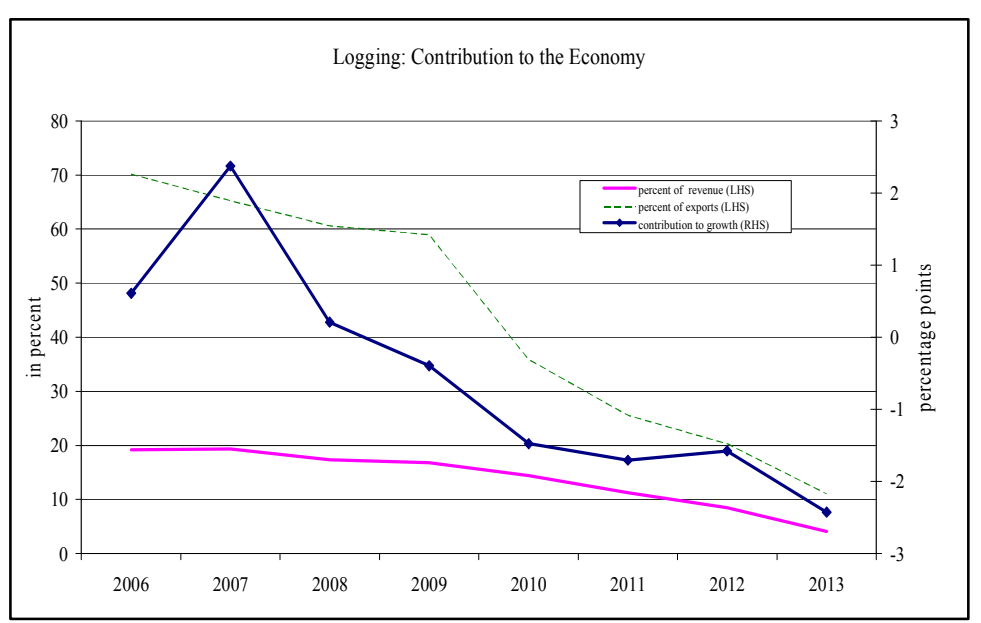
reforestation projects to occur, favorable international prices, and continued strong demand from major log importers such as China. The recent acceleration of logging activity has hastened the depletion of the natural forests to the extent that by 2013 , experts predict there will be no natural commercially viable $\operatorname{logs}$ left.

To help slow down logging activity, the government has recently passed some measures. These include: (i) the cancellation of licenses of logging companies who fail to submit acceptable public environment reports; (ii) the issuance of a directive to the Foreign Investment Board not to approve any new application for logging operations; and (iii) adjusting the reference prices of logs from an average of US\$71 to US\$78 per cubic meter effective May 1, 2008. However, the government has backtracked on announced plans to further increase reference prices to US\$85 by June 1, 2008 and reintroduce an automatic price adjustment mechanism to bring reference prices in line with movements in market prices.

\section{Despite the recent} adjustment, reference prices of logs remain well below international market prices, resulting in foregone government revenues. Despite the May 1 increase, reference prices remain about 72 percent below average international prices. The delayed adjustment in reference prices of logs to reflect market values has resulted in lost tax revenues, estimated at about 3.0 percent of GDP in 2006 and 33/4 percent of GDP in 2007. Rough estimates show that foregone revenues would be as high as 10 percent of GDP in 2008 . 
Figure 1. Solomon Islands: Graphical Summary of Recent Macroeconomic Developments

Real GDP growth reached 10.3 percent in 2007, driven by strong growth in the primary sector.

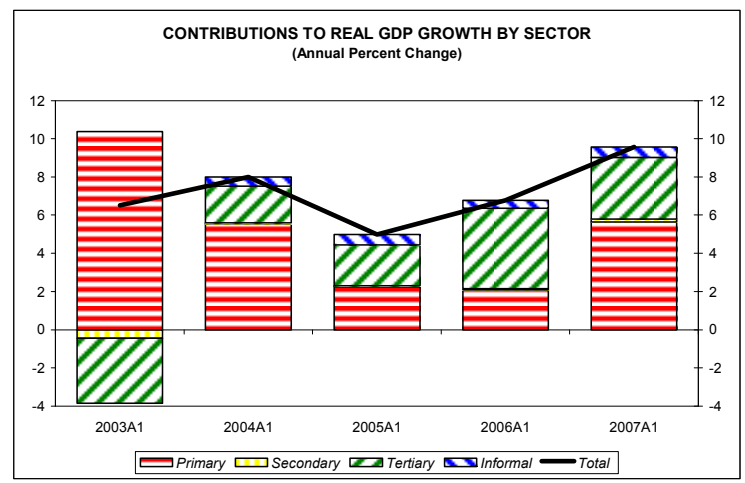

The trade deficit widened to 19 percent of GDP in 2007, reflecting a deterioration in the terms of trade.

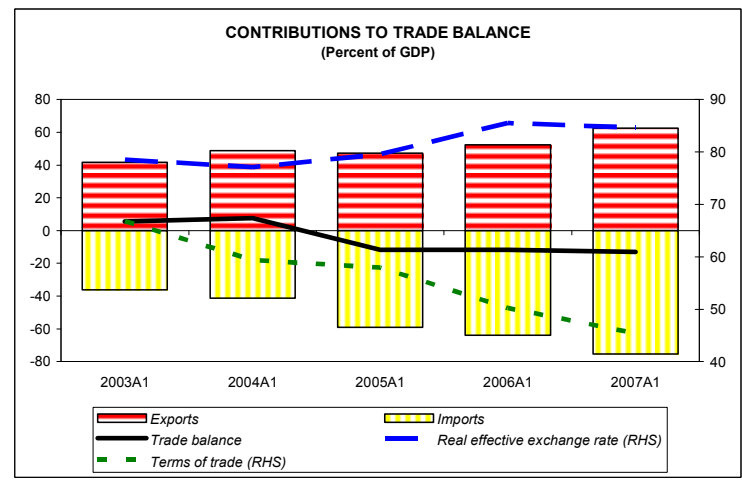

The overall fiscal balance swung to a deficit of 1.5 percent of GDP in 2007 from a surplus of 1.7 percent of GDP in 2006, outperforming the budget.

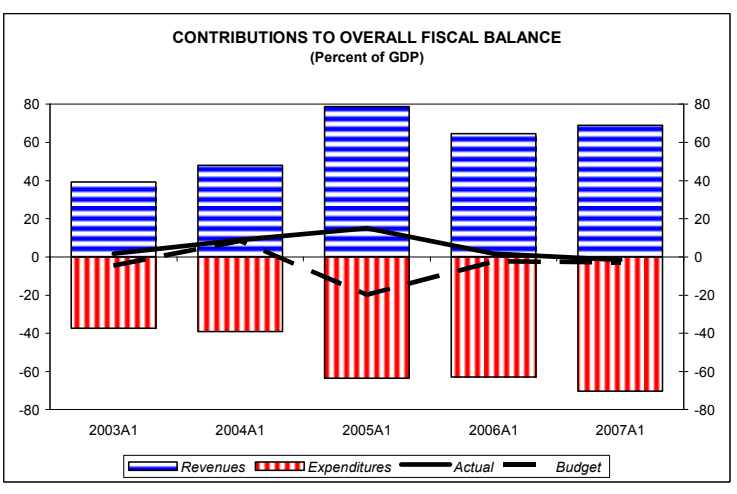

Inflation rose sharply in 2008 , primarily due to international food and fuel prices.

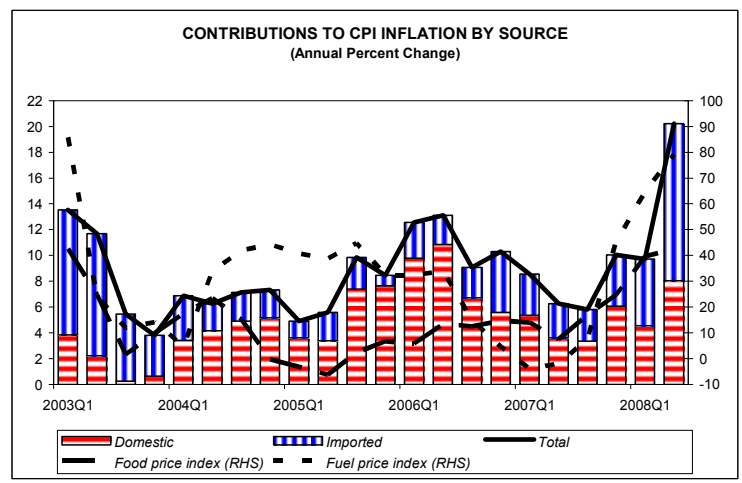

The current account deficit narrowed to 3 percent of GDP in 2007, while reserve coverage remained stable at 4 months of projected imports.

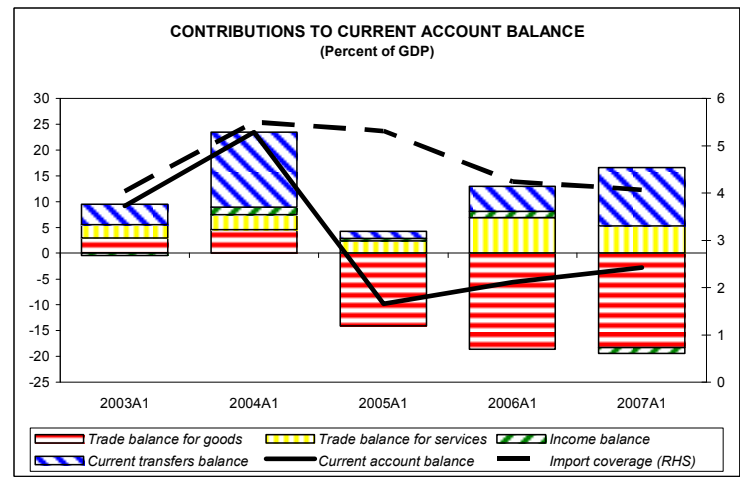

Private sector credit growth of about 55 percent in 2007 supported high domestic inflation.

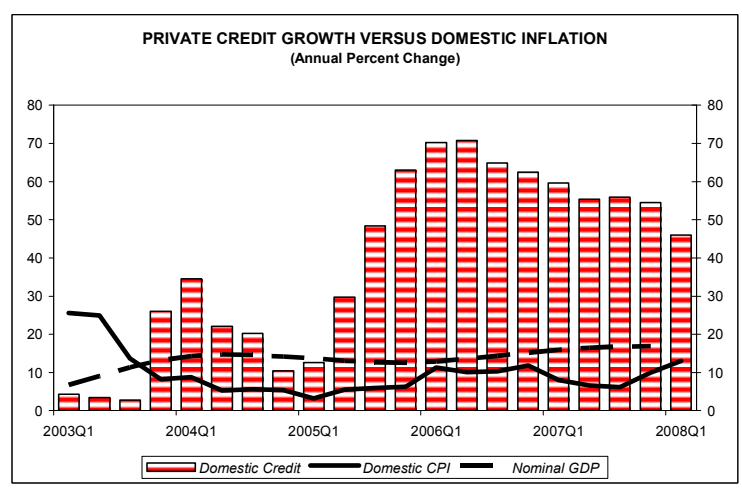


Figure 2. Solomon Islands: Projections of Key Macroeconomic Variables under Baseline and Alternative Scenarios
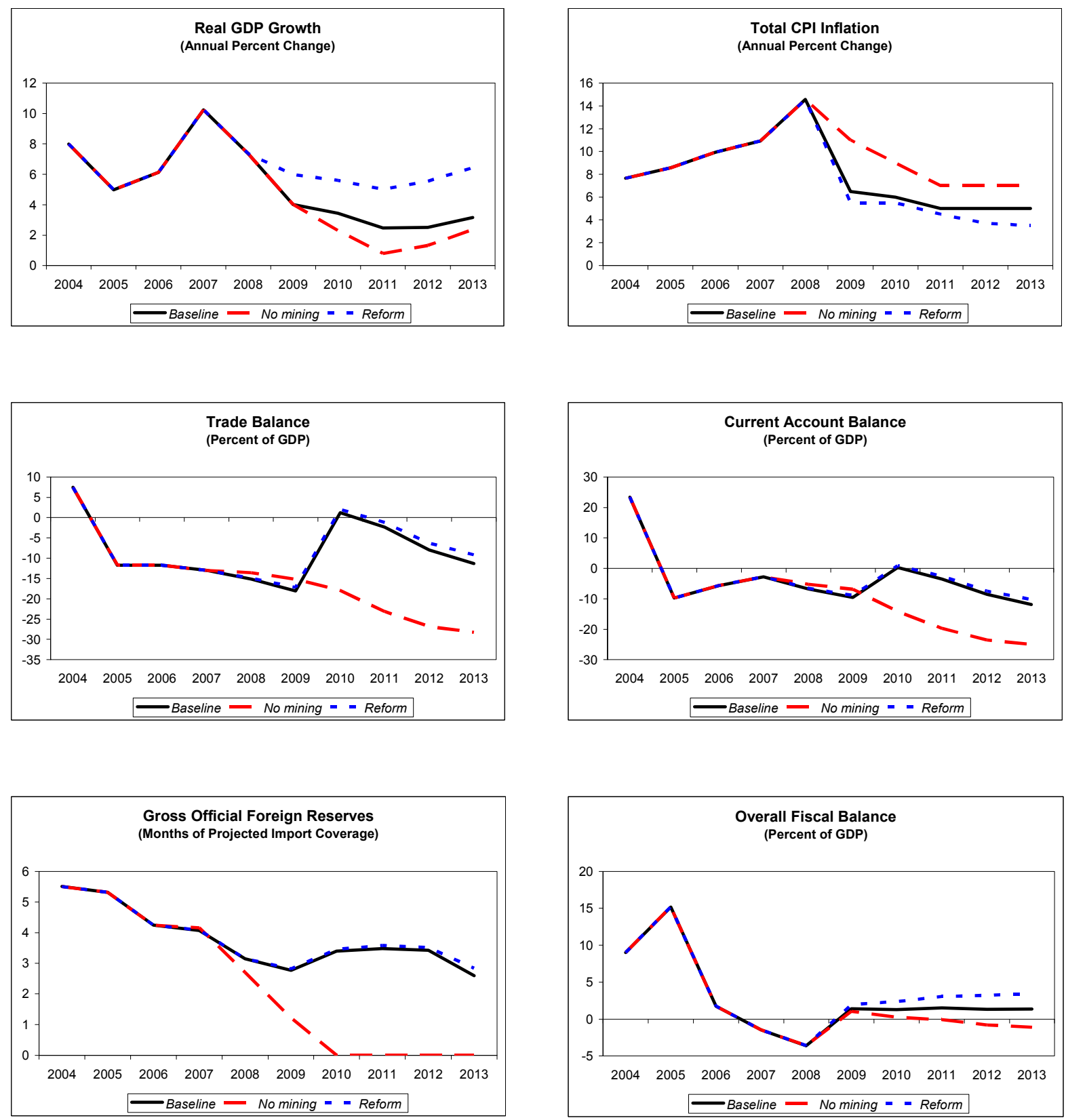
Table 1. Solomon Islands: Selected Economic Indicators, 2003-09

$\begin{array}{ll}\text { Nominal GDP (2007): } & \text { US } \$ 388 \text { million } \\ \text { Population (2007): } & 508,420 \\ \text { GDP per capita (2007): } & \text { US } \$ 764 \\ \text { Quota: } & \text { SDR } 10.4 \text { million }\end{array}$

\begin{tabular}{|c|c|c|c|c|c|c|c|}
\hline & \multirow[t]{2}{*}{2003} & \multirow[t]{2}{*}{2004} & \multirow[t]{2}{*}{2005} & \multirow[t]{2}{*}{2006} & \multirow{2}{*}{$\begin{array}{r}2007 \\
\text { Est. }\end{array}$} & 2008 & 2009 \\
\hline & & & & & & \multicolumn{2}{|c|}{ Proj. } \\
\hline \multicolumn{8}{|l|}{ Growth and prices (percentage change) } \\
\hline Real GDP & 6.5 & 8.0 & 5.0 & 6.1 & 10.3 & 7.3 & 4.0 \\
\hline CPI (period average) & 10.0 & 6.9 & 7.4 & 11.2 & 7.7 & 15.1 & 8.8 \\
\hline CPI (end of period) & 3.7 & 7.6 & 8.6 & 9.9 & 10.9 & 14.6 & 6.5 \\
\hline Per capita GDP (in US\$) & 503 & 560 & 609 & 676 & 764 & 905 & 966 \\
\hline \multicolumn{8}{|l|}{ Central government operations (percent of GDP) } \\
\hline Total revenue & 39.2 & 48.1 & 66.2 & 64.7 & 69.0 & 61.6 & 60.7 \\
\hline Recurrent revenue & 21.2 & 26.3 & 29.7 & 32.3 & 36.8 & 33.0 & 32.4 \\
\hline Grants & 18.0 & 21.8 & 36.6 & 32.5 & 32.2 & 28.6 & 28.3 \\
\hline Total expenditure $1 /$ & 37.4 & 39.1 & 63.6 & 63.0 & 70.4 & 65.2 & 59.3 \\
\hline Recurrent expenditure & 21.9 & 21.6 & 26.7 & 30.7 & 33.0 & 35.3 & 30.1 \\
\hline Development expenditure & 15.5 & 17.4 & 36.9 & 32.3 & 37.5 & 29.8 & 29.2 \\
\hline Overall balance 2/ & 1.8 & 9.0 & 2.6 & 1.7 & -1.5 & -3.6 & 1.4 \\
\hline Foreign financing (net) & 0.8 & 0.0 & 4.7 & 2.1 & 3.2 & -1.0 & -1.7 \\
\hline Domestic financing (net) & -9.3 & -6.7 & -2.3 & -1.8 & -1.1 & 4.2 & 0.1 \\
\hline Other & 9.9 & -2.3 & -3.0 & -0.3 & -0.5 & 0.3 & 0.1 \\
\hline Discrepancy (neg. are net expenditures) & -3.3 & 0.0 & -2.0 & 1.8 & 0.1 & 0.0 & 0.0 \\
\hline Central government debt (percent of GDP) $3 /$ & 120.4 & 88.6 & 72.6 & 63.5 & 52.3 & 41.9 & 36.1 \\
\hline Domestic & 51.5 & 30.1 & 24.0 & 18.1 & 14.4 & 11.6 & 10.0 \\
\hline External & 68.9 & 58.4 & 48.6 & 45.4 & 37.9 & 30.3 & 26.1 \\
\hline External debt (in US $\$$ millions, end of period) & 157.7 & 153.1 & 142.6 & 151.7 & 147.3 & 143.1 & 135.5 \\
\hline External debt service to exports of GNFS (accrual basis) & 5.0 & 3.5 & 5.3 & 2.5 & 5.2 & 2.9 & 4.2 \\
\hline \multicolumn{8}{|l|}{ Monetary and credit (percentage change, end-year data) } \\
\hline M3 & 25.4 & 19.5 & 38.9 & 26.4 & 24.0 & 16.1 & 14.6 \\
\hline Base Money & 26.5 & 75.7 & 20.0 & 8.1 & -2.0 & -5.0 & 11.6 \\
\hline Interest rate (3-month t/bill rate, average) & 5.8 & 6.0 & 4.5 & 3.4 & 3.2 & $\ldots$ & $\ldots$ \\
\hline \multicolumn{8}{|l|}{ Balance of payments (US\$ millions, unless otherwise indicated) } \\
\hline Current account & 20.9 & 61.5 & -28.7 & -18.8 & -10.8 & -32.2 & -49.9 \\
\hline (Percent of GDP) & 9.1 & 23.5 & -9.8 & -5.6 & -2.8 & -6.8 & -9.6 \\
\hline Overall balance (accrual) & 18.8 & 43.4 & 16.0 & 9.4 & 17.0 & -19.3 & -8.8 \\
\hline Gross official reserves (US\$ millions, end of period) & 36.3 & 79.5 & 94.6 & 103.5 & 119.8 & 100.5 & 91.7 \\
\hline (in months of projected imports of GNFS) & 4.0 & 5.5 & 5.3 & 4.2 & 4.1 & 3.1 & 2.8 \\
\hline Exchange rate (SI\$/US\$, end of period) & 7.49 & 7.51 & 7.58 & 7.62 & 7.66 & $\ldots$ & $\ldots$ \\
\hline Real effective exchange rate (period average, $2000=100$ ) & 78.5 & 77.1 & 79.5 & 85.5 & 84.7 & $\ldots$ & $\ldots$ \\
\hline Nominal effective exchange rate (period average, $2000=100$ ) & 64.4 & 60.3 & 59.1 & 58.5 & 55.0 & $\ldots$ & $\ldots$ \\
\hline
\end{tabular}

Sources: Data provided by the authorities; and Fund staff estimates and projections.

1/ Expenditures are presented on an accrual basis.

2/ Calculated from above-the-line data.

$3 /$ Includes arrears. 
Table 2. Solomon Islands: Central Government Operations, 2003-09

(In percent of GDP)

\begin{tabular}{|c|c|c|c|c|c|c|c|c|}
\hline & \multirow[t]{2}{*}{2003} & \multirow[t]{2}{*}{2004} & \multirow[t]{2}{*}{2005} & \multirow[t]{2}{*}{2006} & \multirow{2}{*}{$\begin{array}{r}2007 \\
\text { Revised } \\
\text { Budget }\end{array}$} & \multirow{2}{*}{$\begin{array}{r}2007 \\
\text { Est. }\end{array}$} & \multirow{2}{*}{$\frac{2008}{\text { Proj. }}$} & \multirow[t]{2}{*}{2009} \\
\hline & & & & & & & & \\
\hline Total revenue and grants & 39.2 & 48.1 & 66.2 & 64.7 & 66.1 & 69.0 & 61.6 & 60.7 \\
\hline Total revenue & 21.2 & 26.3 & 29.7 & 32.3 & 29.8 & 36.8 & 33.0 & 32.4 \\
\hline Tax revenue & 19.4 & 23.6 & 25.2 & 26.7 & 25.8 & 31.1 & 29.3 & 28.7 \\
\hline Other revenue & 1.8 & 2.7 & 4.5 & 5.5 & 4.1 & 5.7 & 3.7 & 3.7 \\
\hline Grants 1/ & 18.0 & 21.8 & 36.6 & 32.5 & 36.3 & 32.2 & 28.6 & 28.3 \\
\hline Expenditure 2/ & 37.4 & 39.1 & 63.6 & 63.0 & 68.9 & 70.4 & 65.2 & 59.3 \\
\hline $\begin{array}{l}\text { Recurrent expenditure } 3 / \\
\text { Of which: }\end{array}$ & 21.9 & 21.6 & 26.7 & 30.7 & 28.1 & 33.0 & 35.3 & 30.1 \\
\hline Compensation of employees & 9.3 & 8.8 & 10.6 & 9.8 & 11.0 & 11.9 & 10.9 & 10.4 \\
\hline Goods and services & 5.8 & 7.8 & 11.1 & 16.4 & 13.7 & 16.7 & 16.0 & 16.8 \\
\hline Development expenditure & 15.5 & 17.4 & 36.9 & 32.3 & 40.8 & 37.5 & 29.8 & 29.2 \\
\hline Overall balance (above the line) & 1.8 & 9.0 & 2.6 & 1.7 & -2.8 & -1.5 & -3.6 & 1.4 \\
\hline Discrepancy (neg. are net expenditures) & -3.3 & 0.0 & -2.0 & 1.8 & 0.0 & 0.1 & 0.0 & 0.0 \\
\hline Financing & 1.4 & -9.0 & -0.6 & 0.1 & 2.8 & 1.6 & 3.6 & -1.4 \\
\hline Foreign (net) & 0.8 & 0.0 & 4.7 & 2.1 & $\ldots$ & 3.2 & -1.0 & -1.7 \\
\hline Domestic bank and nonbank (net) & -9.3 & -6.7 & -2.3 & -1.8 & $\ldots$ & -1.1 & 4.2 & 0.1 \\
\hline Banking system (accrual) & -9.1 & -8.7 & -1.9 & -1.9 & $\ldots$ & -0.7 & 4.4 & 0.3 \\
\hline Nonbank (accrual) & -0.2 & 2.0 & -0.4 & 0.1 & $\ldots$ & -0.5 & -0.2 & -0.1 \\
\hline Privatization receipts & 0.0 & 0.0 & 0.0 & 0.3 & $\ldots$ & 0.0 & 0.6 & 0.0 \\
\hline Increase in expenditure arrears 4/ & 4.1 & -5.2 & -3.4 & -0.6 & $\ldots$ & -0.5 & -0.2 & 0.1 \\
\hline Principal debt arrears & 5.8 & -10.0 & 0.4 & 0.0 & $\ldots$ & 0.0 & 0.0 & 0.0 \\
\hline Restructured Bonds & 0.0 & 12.8 & 0.0 & 0.0 & $\ldots$ & 0.0 & 0.0 & 0.0 \\
\hline
\end{tabular}

Sources: Data provided by the authorities; and Fund staff estimates and projections.

1/ Based on donors' commitments through 2010.

2/ On an accrual basis.

$3 /$ Includes the supplementary budget for 2008 .

4/ Includes interest arrears. 
Table 3. Solomon Islands: Summary Accounts of the Banking System, 2003-08 (In millions of S.I. dollars, end of period)

\begin{tabular}{|c|c|c|c|c|c|c|}
\hline & 2003 & 2004 & 2005 & 2006 & $\begin{array}{r}2007 \\
\text { Est. }\end{array}$ & $\begin{array}{l}2008 \\
\text { Proj. }\end{array}$ \\
\hline \multicolumn{7}{|l|}{ Central Bank } \\
\hline Assets & 486.1 & 806.0 & 942.2 & 1004.0 & 1143.1 & 1057.5 \\
\hline Foreign & 271.1 & 596.8 & 716.9 & 790.5 & 918.0 & 788.2 \\
\hline Government & 185.5 & 185.6 & 196.9 & 161.7 & 149.7 & 172.5 \\
\hline Other & 29.5 & 23.7 & 28.4 & 51.8 & 75.4 & 96.8 \\
\hline Liabilities & 486.1 & 806.0 & 942.2 & 1004.0 & 1143.1 & 1057.5 \\
\hline Foreign & 21.5 & 22.5 & 17.2 & 17.4 & 44.5 & 69.5 \\
\hline Currency in circulation & 111.2 & 137.7 & 168.0 & 203.4 & 262.9 & 327.0 \\
\hline Deposits & 202.8 & 451.9 & 575.2 & 534.8 & 475.9 & 323.4 \\
\hline Other & 150.5 & 193.9 & 181.7 & 248.4 & 359.7 & 337.5 \\
\hline Capital & -28.4 & 16.3 & 158.6 & 158.6 & 209.1 & 261.5 \\
\hline \multicolumn{7}{|l|}{ Commercial Banks } \\
\hline Assets & 612.2 & 775.6 & 990.6 & 1273.1 & 1505.3 & 1906.9 \\
\hline Capital & 99.6 & 121.1 & 159.2 & 180.2 & 188.3 & 247.3 \\
\hline Reserves & 115.3 & 260.4 & 309.5 & 313.0 & 243.2 & 153.7 \\
\hline Required & 32.0 & 40.9 & 54.9 & 72.9 & 86.6 & 103.7 \\
\hline Excess & 83.4 & 219.5 & 254.6 & 240.0 & 156.6 & 50.0 \\
\hline \multicolumn{7}{|l|}{ Monetary Survey } \\
\hline Net foreign assets & 266.1 & 579.9 & 712.5 & 770.0 & 852.0 & 669.9 \\
\hline Central bank & 249.6 & 574.2 & 699.7 & 773.1 & 873.5 & 718.6 \\
\hline Commercial banks & 16.5 & 5.7 & 12.8 & -3.1 & -21.5 & -48.7 \\
\hline Domestic credit & 466.5 & 316.5 & 425.6 & 621.0 & 946.0 & 1374.9 \\
\hline Private sector & 217.3 & 238.6 & 389.1 & 632.3 & 976.9 & 1342.8 \\
\hline Public sector & 249.2 & 77.9 & 36.4 & -11.2 & -30.9 & 32.1 \\
\hline M1 & 327.9 & 371.8 & 537.9 & 703.4 & 909.7 & 1097.4 \\
\hline Currency in circulation & 102.7 & 123.2 & 153.0 & 177.6 & 232.0 & 280.7 \\
\hline Demand deposits & 225.2 & 248.6 & 384.9 & 525.8 & 677.7 & 816.7 \\
\hline M2 & 395.4 & 447.8 & 626.0 & 802.4 & 1032.2 & 1241.1 \\
\hline Savings deposits & 67.5 & 76.0 & 88.1 & 98.9 & 122.4 & 143.7 \\
\hline M3 & 520.2 & 621.7 & 863.7 & 1091.6 & 1353.0 & 1570.7 \\
\hline Time deposits & 124.8 & 173.9 & 237.8 & 289.2 & 320.9 & 329.6 \\
\hline Other items net & 212.4 & 274.7 & 274.3 & 299.5 & 445.0 & 474.1 \\
\hline \multicolumn{7}{|l|}{ Memorandum Items } \\
\hline Base money & 226.5 & 398.1 & 477.5 & 516.4 & 506.1 & 480.8 \\
\hline \multicolumn{7}{|c|}{ Interest rates (percent per annum) } \\
\hline Deposit rate & 0.92 & 0.96 & 0.98 & 1.00 & 0.71 & 0.50 \\
\hline Lending rate & 14.70 & 14.29 & 14.12 & 13.92 & 14.12 & 14.23 \\
\hline
\end{tabular}

Sources: Data provided by the Central Bank of the Solomon Islands; and Fund Staff estimates and projections. 
Table 4. Solomon Islands: Balance of Payments, 2006-13

(In millions of U.S. dollars)

\begin{tabular}{|c|c|c|c|c|c|c|c|c|}
\hline & 2006 & 2007 & 2008 & 2009 & 2010 & 2011 & 2012 & 2013 \\
\hline & & Est. & \multicolumn{6}{|c|}{ Proj. } \\
\hline Current account balance & -18.8 & -10.8 & -32.2 & -49.9 & 1.7 & -21.1 & -54.8 & -80.6 \\
\hline In percent of GDP & -5.6 & -2.8 & -6.8 & -9.6 & 0.3 & -3.5 & -8.6 & -11.9 \\
\hline Trade balance for goods & -62.1 & -71.1 & -94.8 & -118.3 & -19.6 & -42.6 & -81.5 & -109.4 \\
\hline Exports & 121.4 & 168.9 & 200.7 & 204.1 & 313.2 & 300.8 & 280.2 & 273.5 \\
\hline Of which: Logs & 84.6 & 109.6 & 126.5 & 125.1 & 108.1 & 69.5 & 38.5 & 24.5 \\
\hline Of which: Fish & 19.2 & 19.8 & 23.6 & 24.4 & 25.8 & 29.0 & 32.2 & 33.9 \\
\hline Of which: Minerals & 0.8 & 0.9 & 0.9 & 0.9 & 122.7 & 142.7 & 146.8 & 148.8 \\
\hline Imports & -183.5 & -240.0 & -295.5 & -322.4 & -332.8 & -343.4 & -361.7 & -383.0 \\
\hline Of which: Food & -21.6 & -30.2 & -38.0 & -39.1 & -39.8 & -40.0 & -40.3 & -40.6 \\
\hline Of which: Fuel & -54.4 & -56.8 & -91.0 & -99.6 & -106.8 & -108.7 & -110.3 & -113.2 \\
\hline Trade balance for services & 23.0 & 20.5 & 23.2 & 24.7 & 26.5 & 28.6 & 30.5 & 32.4 \\
\hline Income balance & 4.3 & -4.2 & -7.2 & -7.9 & -37.3 & -40.3 & -40.5 & -40.8 \\
\hline Current transfers balance & 16.1 & 44.0 & 46.7 & 51.6 & 32.0 & 33.2 & 36.6 & 37.2 \\
\hline Capital account balance & 29.4 & 36.0 & 43.8 & 43.4 & 38.4 & 33.6 & 31.4 & 32.2 \\
\hline Financial account balance & -16.0 & -20.9 & -30.9 & -2.2 & -15.4 & -3.3 & 28.3 & 54.2 \\
\hline Direct investment balance & 11.5 & 33.8 & 35.8 & 59.7 & 31.9 & 28.9 & 52.2 & 76.9 \\
\hline Other investment balance & -27.4 & -54.7 & -66.6 & -61.9 & -47.2 & -32.3 & -23.9 & -22.6 \\
\hline Errors and omissions & 14.7 & 12.7 & 0.0 & 0.0 & 0.0 & 0.0 & 0.0 & 0.0 \\
\hline Overall balance & 9.4 & 17.0 & -19.3 & -8.8 & 24.7 & 9.1 & 4.9 & 5.9 \\
\hline \multicolumn{9}{|l|}{ Memorandum Items } \\
\hline Gross official foreign reserves & 103.5 & 119.8 & 100.5 & 91.7 & 116.4 & 125.5 & 130.5 & 136.4 \\
\hline In months of current import coverage & 5.8 & 4.9 & 3.4 & 2.9 & 3.5 & 3.7 & 3.6 & 3.6 \\
\hline In months of projected import coverage & 4.2 & 4.1 & 3.1 & 2.8 & 3.4 & 3.5 & 3.4 & 2.6 \\
\hline Gross external debt (percent of GDP) & 52.8 & 44.1 & 36.5 & 32.3 & 29.4 & 26.4 & 24.1 & 22.1 \\
\hline Private sector & 7.4 & 6.2 & 6.2 & 6.2 & 6.2 & 6.2 & 6.2 & 6.2 \\
\hline Public sector & 45.4 & 37.9 & 30.3 & 26.1 & 23.2 & 20.2 & 17.9 & 15.9 \\
\hline External debt service (percent of GDP) & 1.3 & 3.2 & 1.7 & 2.4 & 2.1 & 2.2 & 1.9 & 1.8 \\
\hline Principal & 1.0 & 2.4 & 1.1 & 1.6 & 1.3 & 1.5 & 1.2 & 1.1 \\
\hline Interest & 0.4 & 0.8 & 0.7 & 0.7 & 0.8 & 0.8 & 0.7 & 0.7 \\
\hline Nominal GDP & 334.1 & 388.3 & 472.8 & 518.8 & 555.9 & 598.3 & 639.0 & 679.8 \\
\hline
\end{tabular}

Sources: Data provided by the authorities; and Fund Staff estimates and projections. 
Table 5. Solomon Islands: Indicators of External Vulnerability, 2003-09

\begin{tabular}{|c|c|c|c|c|c|c|c|}
\hline & 2003 & 2004 & 2005 & 2006 & 2007 & 2008 & 2009 \\
\hline & & & & & Est. & & \\
\hline \multicolumn{8}{|l|}{ Financial indicators } \\
\hline Government sector debt (in percent of GDP) & 120.4 & 88.6 & 72.6 & 63.5 & 52.3 & 41.9 & 36.1 \\
\hline Broad money (percent change, 12-month basis) & 25.4 & 19.5 & 38.9 & 26.4 & 24.0 & 16.1 & 14.6 \\
\hline Private sector credit (percent change, 12 month basis) & 25.4 & 9.8 & 63.1 & 62.5 & 54.5 & 37.5 & 19.8 \\
\hline 3 month T-bill yield (in percent, nominal) & 5.8 & 6.0 & 4.5 & 3.4 & 3.2 & $\ldots$ & $\ldots$ \\
\hline 3 month T-bill yield (in percent, real) & 2.1 & -1.6 & -4.0 & -6.6 & -7.7 & $\ldots$ & $\ldots$ \\
\hline \multicolumn{8}{|l|}{ External indicators } \\
\hline Merch. Exports (percent change, 12-month basis in US\$) & 28.5 & 30.7 & 5.7 & 18.2 & 39.2 & 18.8 & 1.7 \\
\hline Of which : Non-timber exports & 23.1 & 39.4 & 0.9 & 5.4 & 61.1 & 25.1 & 6.5 \\
\hline Merch. Imports (percent change, 12-month basis in US\$) & 4.5 & 26.1 & 68.9 & 27.5 & 30.8 & 23.1 & 9.1 \\
\hline Terms of trade (percent change, 12 month basis) & -16.6 & -11.1 & -2.4 & -13.3 & -9.6 & -13.7 & -2.2 \\
\hline Current account balance (in percent of GDP) & 9.1 & 23.5 & -9.8 & -5.6 & -2.8 & -6.8 & -9.6 \\
\hline Capital account balance (in percent of GDP) & 5.5 & 0.6 & 9.4 & 8.8 & 9.3 & 9.3 & 8.4 \\
\hline Gross official reserves (in US\$ millions) & 36.3 & 79.5 & 94.6 & 103.5 & 119.8 & 100.5 & 91.7 \\
\hline Central Bank short-term foreign liabilities (in US\$ millions) & 2.9 & 3.0 & 2.3 & 2.3 & 5.8 & 8.9 & 10.6 \\
\hline Central Bank foreign currency exposure (in US\$) & 33.4 & 76.5 & 92.4 & 101.2 & 114.0 & 91.7 & 81.1 \\
\hline Foreign currency exposure of the financial sector (in US\$ millions) $1 /$ & 2.2 & 0.8 & 1.7 & -0.4 & -2.8 & -6.2 & -7.5 \\
\hline Official reserves (in months of next year's imports of GNFS) & 4.0 & 5.5 & 5.3 & 4.2 & 4.1 & 3.1 & 2.8 \\
\hline Gross international reserves to broad money & 52.3 & 96.0 & 83.0 & 72.2 & 67.9 & 50.2 & 41.5 \\
\hline Total external public sector debt (in percent of GDP) 2/ & 68.9 & 58.4 & 48.6 & 45.4 & 37.9 & 30.3 & 26.1 \\
\hline Total external debt to exports of GNFS 3/ & 192.9 & 140.4 & 120.7 & 101.1 & 70.8 & 61.3 & 57.8 \\
\hline External interest payments to exports of GNFS $3 /$ & 2.7 & 2.1 & 4.0 & 0.7 & 1.3 & 1.1 & 1.3 \\
\hline External amortization payments to exports of GNFS 3 / & 2.3 & 1.4 & 1.3 & 1.8 & 3.8 & 1.8 & 2.9 \\
\hline Exchange rate (SI\$/US\$, period average) & 7.51 & 7.48 & 7.53 & 7.61 & 7.65 & 7.71 & 8.01 \\
\hline Exchange rate (SI\$/US\$, end of period) & 7.49 & 7.51 & 7.58 & 7.62 & 7.66 & $\ldots$ & $\ldots$ \\
\hline REER appreciation (+) (period average) & -12.9 & -1.8 & 3.1 & 7.5 & -1.0 & $\ldots$ & $\ldots$ \\
\hline
\end{tabular}

Sources: Data provided by the authorities; and Fund staff estimates and projections.

$1 /$ Net foreign assets of commercial banks.

2/ Includes arrears.

$3 /$ Includes both public and private sector external debt. 
Table 6. Solomon Islands: Medium-Term Baseline Scenario, 2005-13

\begin{tabular}{|c|c|c|c|c|c|c|c|c|c|}
\hline & 2005 & 2006 & 2007 & 2008 & 2009 & 2010 & 2011 & 2012 & 2013 \\
\hline & & & Est. & \multicolumn{6}{|c|}{ Projection } \\
\hline \multicolumn{10}{|l|}{ Growth and prices (percentage change) } \\
\hline Real GDP & 5.0 & 6.1 & 10.3 & 7.3 & 4.0 & 3.4 & 2.5 & 2.5 & 3.2 \\
\hline Of which: Nontimber & 4.5 & 6.1 & 8.7 & 6.5 & 5.1 & 5.7 & 6.3 & 5.3 & 4.3 \\
\hline CPI (period average) & 7.4 & 11.2 & 7.7 & 15.1 & 8.8 & 6.2 & 5.5 & 5.0 & 5.0 \\
\hline $\mathrm{CPI}$ (end of period) & 8.6 & 9.9 & 10.9 & 14.6 & 6.5 & 6.0 & 5.0 & 5.0 & 5.0 \\
\hline Nominal GDP (millions of SI\$) & 2,207 & 2,542 & 2,971 & 3,647 & 4,154 & 4,613 & 5,106 & 5,586 & 6,085 \\
\hline Nominal GDP (millions of US\$) & 293 & 334 & 388 & 473 & 519 & 556 & 598 & 639 & 680 \\
\hline Per capita GDP (in US\$) & 609 & 676 & 764 & 905 & 966 & 1,006 & 1,054 & 1,095 & 1,133 \\
\hline Per capita GDP in 2008 prices (in US\$) & 802 & 819 & 879 & 918 & 928 & 934 & 931 & 928 & 932 \\
\hline \multicolumn{10}{|l|}{ Central government operations (percent of GDP) } \\
\hline Total revenue and grants & 66.2 & 64.7 & 69.0 & 61.6 & 60.7 & 45.9 & 44.0 & 43.4 & 42.4 \\
\hline Recurrent revenue & 29.7 & 32.3 & 36.8 & 33.0 & 32.4 & 31.9 & 31.0 & 30.4 & 30.4 \\
\hline Grants 1/ & 36.6 & 32.5 & 32.2 & 28.6 & 28.3 & 14.0 & 13.0 & 13.0 & 12.0 \\
\hline Total expenditure $2 /$ & 63.6 & 63.0 & 70.4 & 65.2 & 59.3 & 44.6 & 42.5 & 42.1 & 41.0 \\
\hline Recurrent expenditure & 26.7 & 30.7 & 33.0 & 35.3 & 30.1 & 29.5 & 28.1 & 27.6 & 27.3 \\
\hline Development expenditure $1 /$ & 36.9 & 32.3 & 37.5 & 29.8 & 29.2 & 15.1 & 14.3 & 14.5 & 13.7 \\
\hline Overall balance $3 /$ & 2.6 & 1.7 & -1.5 & -3.6 & 1.4 & 1.3 & 1.5 & 1.3 & 1.4 \\
\hline Central government debt (percent of GDP) 4/ & 72.6 & 63.5 & 52.3 & 41.9 & 36.1 & 31.7 & 27.6 & 24.1 & 21.6 \\
\hline \multicolumn{10}{|l|}{ Monetary and credit (percentage change, end-year data) } \\
\hline Broad money & 38.9 & 26.4 & 24.0 & 16.1 & 14.6 & 11.9 & 11.0 & 9.8 & 9.2 \\
\hline Interest rate (3-month t/bill rate, average) & 4.5 & 3.4 & 3.2 & $\cdots$ & $\ldots$ & $\ldots$ & $\ldots$ & $\cdots$ & $\ldots$ \\
\hline \multicolumn{10}{|l|}{ Balance of payments } \\
\hline Current account & -28.7 & -18.8 & -10.8 & -32.2 & -49.9 & 1.7 & -21.1 & -54.8 & -80.6 \\
\hline (Percent of GDP) & -9.8 & -5.6 & -2.8 & -6.8 & -9.6 & 0.3 & -3.5 & -8.6 & -11.9 \\
\hline Overall balance (accrual) & 16.0 & 9.4 & 17.0 & -19.3 & -8.8 & 24.7 & 9.1 & 4.9 & 5.9 \\
\hline Gross official reserves (US\$ millions, end of period) & 94.6 & 103.5 & 119.8 & 100.5 & 91.7 & 116.4 & 125.5 & 130.5 & 136.4 \\
\hline (in months of next year's imports of GNFS) & 5.3 & 4.2 & 4.1 & 3.1 & 2.8 & 3.4 & 3.5 & 3.4 & 2.6 \\
\hline
\end{tabular}

Sources: Data provided by the authorities; and Fund Staff estimates and projections.

1/ Based on donor commitments through 2010. Development grants and grant-financed development spending are currently administered by donors, and hence are not under the direct control of the government. They exclude police and military spending, but include TA.

2/ Expenditures are presented on an accrual basis.

$3 /$ Calculated from above-the-line data.

$4 /$ Includes interest arrears. 


\section{INTERNATIONAL MONETARY FUND AND \\ INTERNATIONAL DEVELOPMENT ASSOCIATION}

\section{SOLOMON ISLANDS}

\section{Joint IMF/World Bank Debt Sustainability Analysis 2008}

Prepared by the Staffs of the International Monetary Fund and The International Development Association

Approved by Martin Fetherston and Kalpana Kochhar (IMF) and Carlos Braga and Sanjay Dhar (IDA)

September 10, 2008

\section{Medium-Term Baseline Scenario and DebT Sustainability Analysis ${ }^{1}$}

Solomon Islands' debt declined last year, reflecting arrears payments, debt write-offs, and regular debt servicing. As a result of this improvement in the debt situation, as well as high nominal GDP growth over the past few years, all the debt indicators are projected to fall below their policy-dependent indicative thresholds throughout the medium-term (2008-13) under the baseline scenario. ${ }^{2}$ However, historical scenarios and several stress tests still result in a substantial increase in the debt burden and cause several indicators to rise significantly above their thresholds. Moreover, the medium-term outlook hinges critically on the success of developing nonlogging sectors, including gold mining, to offset the projected sharp decline in logging revenues beyond 2009. If gold mining operations do not start in 2010, the balance of payments and foreign reserves would come under severe pressure. ${ }^{3} B$ ased on these results, the Solomon Islands is classified as in moderate risk of debt distress. However, the vulnerabilities arising from stress tests and the downside risks to the baseline scenario from further delays in starting gold mining operations suggest that the risks to debt sustainability are still significant. Therefore, the country should continue to depend solely on grants until these debt sustainability risks are clearly mitigated.

\footnotetext{
${ }^{1}$ Data on state enterprise and provincial government debt are not available. Therefore, the public debt sustainability analysis is limited to central government debt data.

2 These include the NPV of debt in percent of exports (100 percent), GDP (30 percent), and revenue (200 percent), and the debt service in percent of exports (15 percent) and revenue ( 25 percent).

${ }^{3}$ The operation of the gold mine, initially scheduled for 2008 , has been significantly delayed, due mainly to land ownership issues, as well as problems with securing political risk insurance.
} 


\section{Assumptions for the Medium-Term Baseline Scenario}

Real GDP growth is projected to average 3.8 percent over the medium term. Logging activity is expected to decline sharply, but nonlogging sector growth is projected to average about 6 percent as activity in other sectors picks up, including mining, palm oil production, and tourism. Gold mining operations are assumed to start in 2010.

Inflation is projected to average 7.6 percent over the projection period, influenced largely by the recent sharp increase in commodity prices and past expansionary monetary and fiscal policies, but is expected to decline to 5 percent by the end of the projection period as fuel and food prices stabilize.

The fiscal balance is projected to register an average surplus of 1 percent of GDP over the medium term given the limited availability of financing, the government's commitment to no new borrowing, ${ }^{4}$ and the need to continue to make regular debt service payments. This requires a sharp reduction in spending relative to present levels.

The current account deficit is expected to decline when gold export receipts materialize in 2010, offsetting the decline in logging receipts, but is expected to widen to about 12 percent at the end of the projection period, due mainly to a substantial pick up in nickel mining related imports financed by FDI inflows. ${ }^{5}$ The real effective exchange rate is assumed to be constant.

Aid inflows are expected to drop sharply in 2010, reflecting the current schedule of donor commitments, but FDI from the mining sector (gold and nickel) is expected to increase significantly. Given these developments, reserve cover is projected to fall to about $2 \frac{1}{2}$ months of projected imports by 2013 , but to increase significantly thereafter, assuming that nickel production starts in 2014.

\footnotetext{
${ }^{4}$ Under the baseline scenario, the government is assumed to maintain its policy of no new borrowing. However, starting in 2014, we assume that borrowing to finance development needs will resume, and that the ratio of external debt to GDP will stabilize at its projected end-2013 level.

${ }^{5}$ The Sumitomo Metal Mining Company is expected to invest about US\$2 billion in the Solomon Islands, and plans to start the first phase of nickel production in 2014.
} 
Solomon Islands: Selected Economic Indicators, 2007-28.

\begin{tabular}{|c|c|c|c|c|}
\hline & \multirow{2}{*}{$\begin{array}{r}2007 \\
\text { Est. }\end{array}$} & $2008-2013$ & 2014-2018 & 2019-2028 \\
\hline & & \multicolumn{3}{|c|}{ Proj. } \\
\hline Real GDP (percent change) & 10.3 & 3.8 & 6.9 & 7.3 \\
\hline $\mathrm{CPI}$ (period average, in percent) & 7.7 & 7.6 & 5.0 & 5.0 \\
\hline Per capita GDP (in US\$) & 764 & 1,026 & 1,363 & 2,331 \\
\hline \multicolumn{5}{|l|}{ Central government operations (percent of GDP) } \\
\hline Total revenue and grants & 69.0 & 49.7 & 39.4 & 36.4 \\
\hline Total expenditure $1 /$ & 70.4 & 49.1 & 34.8 & 30.5 \\
\hline Overall balance $2 /$ & -1.5 & 0.6 & 4.6 & 6.0 \\
\hline \multicolumn{5}{|c|}{ Balance of payments (US\$ millions, unless otherwise indicated) } \\
\hline Current account & -10.8 & -39.5 & -51.6 & -165.3 \\
\hline (Percent of GDP) & -2.8 & -6.7 & -6.9 & -7.5 \\
\hline Gross official reserves (US\$ millions, end of period) & 119.8 & 116.8 & 904.3 & $1,208.5$ \\
\hline (in months of projected imports of GNFS) & 4.1 & 3.1 & 15.6 & 13.3 \\
\hline
\end{tabular}

Sources: Data provided by the authorities; and Fund staff estimates.

The debt situation has improved further. The Honiara Club initiative resulted in a shortterm moratorium on principal repayments and the forgiveness of interest payments during the moratorium ( 0.2 percent of GDP), which expired in 2007. It also allowed for debt forgiveness and arrears settlement (1.8 percent of GDP) from the Export Finance and Insurance Corporation (EFIC) subject to the successful completion of an Australia-led review. ${ }^{6}$ This review was completed in April 2007 and the debt has been forgiven. The authorities also settled arrears to foreign creditors amounting to 3.8 percent of GDP, and have been regularly servicing the bulk of their debt obligations. These developments helped bring down total public debt to 52 percent of GDP at end-2007, from 64 percent of GDP in 2006.

\section{Debt Sustainability under the Baseline Scenario}

The external debt sustainability analysis still provides mixed results (Table 1). ${ }^{7}$ At end2007, the NPV of external debt to GDP was 38 percent, above its policy-dependent indicative threshold. However, under the DSA baseline, this ratio is expected to fall below its threshold

\footnotetext{
${ }^{6}$ The Honiara Club is a multilateral forum convened by the government in October 2005 to seek debt relief from its official creditors. Four creditors participated in the Honiara Club, namely, the Export Finance and Insurance Corporation (EFIC), the European Commission, the European Investment Bank, and the International Fund for Agricultural Development.

${ }^{7}$ This analysis assumes that the government remains current on all debt obligations from June 2008, and that all debt in arrears (at end-2007 a total of SI\$ 115 million was in arrears, with about SI\$24 million each to the EU and EIB, and SI\$ 12 million to OPEC) are treated as current short-term obligations with NPV equal to face value.
} 
by end-2008 given debt developments this year and high nominal GDP growth. ${ }^{8}$ All other indicators, including the ratios of the NPV of debt to exports and revenue, and debt service ratios, were below their thresholds, and are expected to decline over time. Compared to the previous joint DSA, debt indicators decline at a faster pace over the medium term due mainly to higher projected GDP growth. ${ }^{9}$

The overall central government debt has declined, but remains relatively high (Table 2). At end-2007, central government domestic debt in nominal terms (including arrears) stood at 14 percent of GDP, well below its 2003 peak of 51 percent. In 2008, it is projected to decline further to 12 percent of GDP, reflecting the continued regular repayment of existing debt. Total central government debt in nominal terms is projected to decline from more than 50 percent of GDP in 2007 to 22 percent of GDP in 2013. Nevertheless, the NPV of public sector debt to revenue, albeit declining, is projected to remain relatively high at an average of more than 70 percent of revenues during the next six years.

\section{Risks to the Debt Dynamics}

\section{There are considerable risks based on stress tests and historical scenarios that reflect the country's continued fragile debt position (Tables 3 and 4).}

- External Debt: If key variables revert to their historical averages, then the NPV of external debt to exports continues to rise, because historical averages for real GDP and export growth are very low, ${ }^{10}$ and the 10 -year average of nondebt creating flows is significantly below recent levels. Among the various stress tests, bound test 2 (export growth at its historical average minus one standard deviation) results in the most extreme increase in both the NPV of debt to exports and the NPV of debt service to exports due to the high volatility of exports. The most extreme stress test for the NPV of debt to GDP is bound test B5 (temporary reversion to historical averages, of real GDP growth, export growth, the U.S. dollar GDP deflator, and net non-debt creating flows, minus one half a standard deviation).

- $\quad$ Public Debt: The ratios of the NPV of public debt to GDP and the NPV of public debt to revenue rise dramatically if GDP growth declines temporarily to its historical

\footnotetext{
${ }^{8}$ The thresholds (see footnote 2) apply to countries with weak policies and institutions, and are discussed in Operational Framework for Debt Sustainability Analysis in Low Income Countries-Further Considerations. Although improving, the Solomon Islands' 3-year average CPIA (2005-2007) of 2.8 remains the lowest among the Pacific Island Countries.

${ }^{9}$ See IMF Country Report No. 07/304.

${ }^{10}$ Real GDP growth was significantly affected by the civil conflict, which resulted in an average growth rate of negative 4 percent over the period 1997-2002.
} 
average (bound test 1). This results in a more than five-fold increase in the current level of the NPV of public debt to revenue.

\section{In addition, other risks related to the country's unstable history could materialize.} Given the country's volatile history and its fragile coalition government, political and economic instability could materialize. At present, logging accounts for about 65 percent of export revenues. In 2010, this ratio is expected to drop to about half, and to become negligible by 2013. Under the baseline scenario, gold export receipts are expected to more than offset this decline (accounting initially for about 40 percent of export receipts in 2010). This would prevent reserves from falling below $2 \frac{1}{2}$ months of projected imports over the medium term. But, if gold mining operations are delayed further, it is unlikely that export earnings (even assuming other nonlogging sectors pickup) can fill the gap created by declining logging activity. The balance of payments could then come under severe pressure and reserves could fall rapidly, necessitating difficult economic adjustments and risking the country's ability to service its debt obligations.

Caution should be exercised in interpreting these results given uncertainties surrounding key variables. Macroeconomic variables are subject to large measurement errors. Donors' plans are uncertain and contingent liabilities are likely to increase if plans, including through hiring external managers, to improve the management and operational efficiency of financially-strapped SOEs are further delayed. ${ }^{11}$

The authorities should continue efforts to reduce debt and refrain from new borrowing over the medium term. In view of impending fiscal pressures from declining logging revenues and committed aid, and the need to sustain progress towards debt sustainability, the authorities should restore fiscal discipline, settle remaining arrears, and refrain from incurring new loans, at least until debt sustainability is firmly established. Vigorously pursuing planned SOE reforms will also be necessary to minimize future contingent liabilities to the budget.

\footnotetext{
${ }^{11}$ Reported contingent liabilities of SOEs are SI\$75 million, but the government has undertaken an extensive audit program for all SOEs which are expected to further clarify the financial position of this sector.
} 
Table 1. Solomon Islands: External Debt Sustainability Framework, Baseline Scenario, 2005-28 1/

(In percent of GDP, unless otherwise indicated)

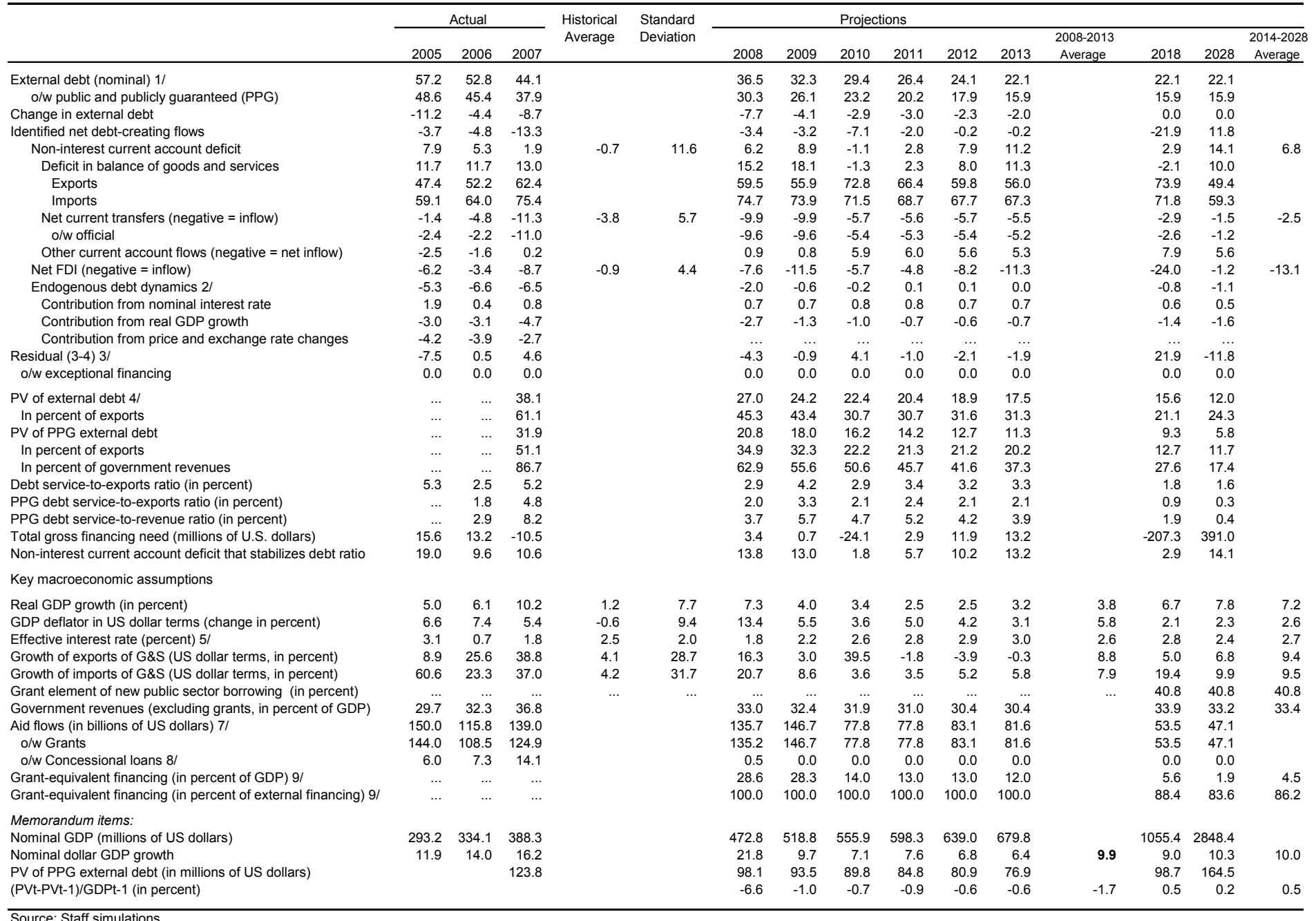

1/ Includes both public and private sector external debt. The DSA exercise was conducted jointly with the World Bank.

Derived as $[r-g-r(1+g))(1+g+r+g)$ (a)

For projections also includes contribution from price and exchange rate changes. Residuals are large in

4/ Assumes that PV of private sector debt is equivalent to its face value.

Historical averages and standard deviations are generally derived over the past 10 years, subject to data availability

$7 /$ Defined as grants, concessional loans, and debt relief.

In 2008, refers to disbursements from previous loans. In line with the government's commitment, no new lows have been incurred.

/ Grant-equivalent financing includes grants provided directly to the government and through new borrowing (difference between the face value and the PV of new debt). 
Table 2. Solomon Islands: Public Sector Debt Sustainability Frmework, Baseline Scenario, 2005-28

(In percent of GDP, unless otherwise indicated)

\begin{tabular}{|c|c|c|c|c|c|c|c|c|c|c|c|c|c|c|c|}
\hline & \multicolumn{3}{|c|}{ Actual } & \multirow[b]{2}{*}{ Average } & \multirow[b]{2}{*}{$\begin{array}{l}\text { Standard } \\
\text { Deviation } \\
\end{array}$} & \multicolumn{5}{|l|}{ Estimate } & \multicolumn{5}{|c|}{ Projections } \\
\hline & 2005 & 2006 & 2007 & & & 2008 & 2009 & 2010 & 2011 & 2012 & 2013 & $\begin{array}{l}2008-13 \\
\text { Average }\end{array}$ & 2018 & 2028 & $\begin{array}{l}2014-28 \\
\text { Average } \\
\end{array}$ \\
\hline $\begin{array}{l}\text { Public sector debt } 1 / \\
\text { o/w foreign-currency denominated }\end{array}$ & $\begin{array}{l}72.6 \\
48.6\end{array}$ & $\begin{array}{l}63.5 \\
45.4\end{array}$ & $\begin{array}{l}52.3 \\
37.9\end{array}$ & & & $\begin{array}{l}41.9 \\
30.3\end{array}$ & $\begin{array}{l}36.1 \\
26.1\end{array}$ & $\begin{array}{l}31.7 \\
23.2\end{array}$ & $\begin{array}{l}27.5 \\
20.2\end{array}$ & $\begin{array}{l}24.0 \\
17.9\end{array}$ & $\begin{array}{l}21.5 \\
15.9\end{array}$ & & $\begin{array}{l}19.0 \\
15.9\end{array}$ & $\begin{array}{l}17.0 \\
15.9\end{array}$ & \\
\hline Change in public sector debt & -14.9 & -9.2 & -11.2 & & & -10.4 & -5.8 & -4.4 & -4.3 & -3.5 & -2.5 & & -0.6 & -0.1 & \\
\hline Identified debt-creating flows & -24.9 & -11.5 & -7.7 & & & -5.9 & -5.5 & -4.1 & -4.0 & -3.2 & -2.9 & & -7.4 & -7.8 & \\
\hline Primary deficit & -16.4 & -2.4 & -0.6 & -1.4 & 8.0 & 2.6 & -2.4 & -2.1 & -2.2 & -1.9 & -1.9 & -1.3 & -5.9 & -6.2 & -5.7 \\
\hline Revenue and grants & 66.2 & 64.7 & 69.0 & & & 61.6 & 60.7 & 45.9 & 44.0 & 43.4 & 42.4 & & 38.9 & 34.9 & \\
\hline of which: grants & 36.6 & 32.5 & 32.2 & & & 28.6 & 28.3 & 14.0 & 13.0 & 13.0 & 12.0 & & 5.1 & 1.7 & \\
\hline Primary (noninterest) expenditure & 62.7 & 62.3 & 68.4 & & & 64.2 & 58.3 & 43.8 & 41.8 & 41.5 & 40.4 & & 33.0 & 28.7 & \\
\hline Automatic debt dynamics & -8.0 & -8.6 & -6.9 & & & -8.0 & -3.1 & -1.9 & -1.8 & -1.3 & -1.0 & & -1.5 & -1.6 & \\
\hline Contribution from interest rate/growth differential & -8.8 & -9.3 & -7.4 & & & -9.0 & -5.2 & -3.6 & -2.9 & -2.2 & -1.8 & & -2.2 & -2.3 & \\
\hline of which: contribution from average real interest rate & -4.7 & -5.1 & -1.5 & & & -5.4 & -3.6 & -2.4 & -2.2 & -1.5 & -1.1 & & -0.9 & -1.0 & \\
\hline of which: contribution from real GDP growth & -4.1 & -4.2 & -5.9 & & & -3.6 & -1.6 & -1.2 & -0.8 & -0.7 & -0.7 & & -1.2 & -1.2 & \\
\hline Contribution from real exchange rate depreciation & 0.8 & 0.7 & 0.5 & & & 1.0 & 2.1 & 1.7 & 1.1 & 0.9 & 0.8 & & $\ldots$ & $\ldots$ & \\
\hline Other identified debt-creating flows & -0.4 & -0.4 & -0.3 & & & -0.6 & 0.0 & 0.0 & 0.0 & 0.0 & 0.0 & & 0.0 & 0.0 & \\
\hline Privatization receipts (negative) & 0.0 & -0.3 & 0.0 & & & -0.6 & 0.0 & 0.0 & 0.0 & 0.0 & 0.0 & & 0.0 & 0.0 & \\
\hline Recognition of implicit or contingent liabilities $2 /$ & 0.0 & 0.0 & 0.0 & & & 0.0 & 0.0 & 0.0 & 0.0 & 0.0 & 0.0 & & 0.0 & 0.0 & \\
\hline Debt relief (HIPC and other) & -0.4 & -0.1 & -0.3 & & & 0.0 & 0.0 & 0.0 & 0.0 & 0.0 & 0.0 & & 0.0 & 0.0 & \\
\hline Other (specify, e.g. bank recapitalization) & 0.0 & 0.0 & 0.0 & & & 0.0 & 0.0 & 0.0 & 0.0 & 0.0 & 0.0 & & 0.0 & 0.0 & \\
\hline Residual, including asset changes $3 /$ & 10.0 & 2.3 & -3.4 & & & -4.4 & -0.3 & -0.3 & -0.2 & -0.3 & 0.5 & & 6.8 & 7.7 & \\
\hline \multicolumn{16}{|l|}{ Other Sustainability Indicators } \\
\hline $\mathrm{PV}$ of public sector debt & $\ldots$ & $\ldots$ & 46.3 & & & 32.3 & 27.9 & 24.6 & 21.4 & 18.7 & 16.9 & & 12.4 & 6.8 & \\
\hline $\mathrm{o} / \mathrm{w}$ foreign-currency denominated & $\ldots$ & $\ldots$ & 31.9 & & & 21.1 & 18.4 & 16.4 & 14.3 & 12.8 & 11.4 & & 9.5 & 5.8 & \\
\hline $\mathrm{o} / \mathrm{w}$ external & $\ldots$ & $\ldots$ & 31.9 & & & 21.1 & 18.4 & 16.4 & 14.3 & 12.8 & 11.4 & & 9.5 & 5.8 & \\
\hline PV of contingent liabilities (not included in public sector debt) & & $\ldots$ & $\ldots$ & & & $\ldots$ & $\ldots$ & $\ldots$ & $\ldots$ & & & & $\ldots$ & & \\
\hline Gross financing need $4 /$ & $\ldots$ & $\ldots$ & 0.5 & & & 5.0 & 5.2 & 0.8 & 0.5 & 0.5 & 0.4 & & -4.1 & -5.9 & \\
\hline $\mathrm{PV}$ of public sector debt-to-revenue and grants ratio (in percent) & & & 67.1 & & & 52.4 & 46.0 & 53.6 & 48.6 & 43.0 & 39.9 & & 31.9 & 19.4 & \\
\hline $\mathrm{PV}$ of public sector debt-to-revenue ratio (in percent) & $\ldots$ & $\ldots$ & 125.7 & & & 97.9 & 86.1 & 77.0 & 68.9 & 61.4 & 55.7 & & 36.7 & 20.3 & \\
\hline o/w external 5/ & $\ldots$ & $\ldots$ & 86.8 & & & 64.0 & 56.6 & 51.4 & 46.2 & 42.1 & 37.7 & & 27.9 & 17.6 & \\
\hline Debt service-to-revenue and grants ratio (in percent) 6/ & $\ldots$ & 3.2 & 6.8 & & & 3.6 & 4.5 & 5.1 & 5.5 & 4.9 & 4.6 & & 2.5 & 0.4 & \\
\hline Debt service-to-revenue ratio (in percent) $6 /$ & $\ldots$ & 2.2 & 5.6 & & & 2.9 & 3.0 & 2.7 & 2.4 & 2.1 & 1.8 & & 0.7 & 0.1 & \\
\hline Primary deficit that stabilizes the debt-to-GDP ratio & -1.6 & 6.7 & 10.6 & & & 13.0 & 3.5 & 2.2 & 2.0 & 1.5 & 0.5 & & -5.3 & -6.1 & \\
\hline \multicolumn{16}{|l|}{ Key macroeconomic and fiscal assumptions } \\
\hline Real GDP growth (in percent) & 5.0 & 6.1 & 10.2 & 1.2 & 7.7 & 7.3 & 4.0 & 3.4 & 2.5 & 2.5 & 3.2 & 3.8 & 6.7 & 7.8 & 7.2 \\
\hline Average nominal interest rate on forex debt (in percent) & 0.7 & 0.2 & 2.1 & 0.9 & 0.7 & 1.1 & 1.3 & 1.3 & 1.3 & 1.3 & 1.3 & 1.3 & 0.6 & 0.1 & 0.5 \\
\hline Average real interest rate on forex debt (in percent) & -2.8 & -4.2 & 2.3 & 7.3 & 11.5 & -7.2 & 0.5 & 2.3 & 0.9 & 1.7 & 2.9 & 0.2 & 1.8 & -1.0 & 0.9 \\
\hline Real exchange rate depreciation (in percent, + indicates depreciation) & 2.1 & 2.7 & 1.7 & 22.3 & 40.1 & 4.0 & $\ldots$ & $\ldots$ & $\ldots$ & $\ldots$ & $\ldots$ & $\ldots$ & $\ldots$ & $\ldots$ & $\ldots$ \\
\hline Inflation rate (GDP deflator, in percent) & 6.6 & 7.4 & 5.4 & -0.6 & 9.4 & 13.4 & 5.5 & 3.6 & 5.0 & 4.2 & 3.1 & 5.8 & 2.1 & 2.3 & 2.6 \\
\hline Growth of real primary spending (deflated by GDP deflator, in percent) & 0.7 & 0.1 & 0.2 & 0.2 & 0.3 & 0.0 & -0.1 & -0.2 & 0.0 & 0.0 & 0.0 & 0.0 & 0.0 & 0.1 & 0.0 \\
\hline Grant element of new external borrowing (in percent) & $\ldots$ & $\ldots$ & $\ldots$ & $\ldots$ & $\ldots$ & $\ldots$ & $\ldots$ & $\ldots$ & $\ldots$ & $\ldots$ & $\ldots$ & $\ldots$ & 40.8 & 40.8 & $\ldots$ \\
\hline
\end{tabular}

The public sector covers only the central government. The DSA exercise was conducted jointly with the World Bank.

/ Reside stimate of recognized contingent liabilities. Remaining contingent liabilities are estimated at 4.3 percent of GDP

Gross finare large in theter half of the projection period due mainly to the large and volatile FDI from the nickel mining company

$5 /$ Revenues excluding grants.

6/ Debt service is defined as the sum of interest and amortization of medium and long-term debt.

7/ Historical averages and standard deviations are generally derived over the past 10 years, subject to data availability. 
Table 3. Solomon Islands: Sensitivity Analysis for Key Indicators of Public and Publicly Guaranteed External Debt, 2008-28 (In percent)

\begin{tabular}{|c|c|c|c|c|c|c|c|c|c|c|c|c|}
\hline & \multicolumn{12}{|c|}{ Projections } \\
\hline & 2008 & 2009 & 2010 & 2011 & 2012 & 2013 & 2014 & 2015 & 2016 & 2017 & 2018 & 2028 \\
\hline \multicolumn{13}{|c|}{ PV of debt-to GDP ratio } \\
\hline Baseline & 21 & 18 & 16 & 14 & 13 & 11 & 11 & 11 & 10 & 10 & 9 & 6 \\
\hline \multicolumn{13}{|l|}{ A. Alternative Scenarios } \\
\hline A1. Key variables at their historical averages in 2008-2028 1/ & 21 & 20 & 23 & 23 & 21 & 20 & 51 & 80 & 88 & 95 & 111 & 52 \\
\hline A2. New public sector loans on less favorable terms in 2008-2028 2 & 21 & 18 & 16 & 14 & 13 & 11 & 12 & 11 & 11 & 11 & 10 & 7 \\
\hline \multicolumn{13}{|l|}{ B. Bound Tests } \\
\hline B1. Real GDP growth at historical average minus one standard deviation in 2009-2010 & 21 & 20 & 20 & 17 & 16 & 14 & 13 & 13 & 12 & 12 & 12 & 7 \\
\hline B2. Export value growth at historical average minus one standard deviation in 2009-2010 3/ & 21 & 28 & 56 & 53 & 51 & 48 & 46 & 44 & 42 & 40 & 38 & 12 \\
\hline B3. US dollar GDP deflator at historical average minus one standard deviation in 2009-2010 & 21 & 21 & 22 & 19 & 17 & 15 & 15 & 14 & 14 & 13 & 13 & 8 \\
\hline B4. Net non-debt creating flows at historical average minus one standard deviation in 2009-2010 4/ & 21 & 36 & 46 & 43 & 40 & 39 & 37 & 35 & 34 & 32 & 30 & 10 \\
\hline B5. Combination of B1-B4 using one-half standard deviation shocks & 21 & 45 & 91 & 86 & 82 & 78 & 75 & 72 & 68 & 65 & 61 & 19 \\
\hline B6. One-time 30 percent nominal depreciation relative to the baseline in 2009 5/ & 21 & 25 & 23 & 20 & 18 & 16 & 15 & 15 & 14 & 14 & 13 & 8 \\
\hline \multicolumn{13}{|c|}{ PV of debt-to-exports ratio } \\
\hline Baseline & 35 & 32 & 22 & 21 & 21 & 20 & 16 & 16 & 13 & 13 & 13 & 12 \\
\hline \multicolumn{13}{|l|}{ A. Alternative Scenarios } \\
\hline A1. Key variables at their historical averages in 2008-2028 1/ & 35 & 37 & 32 & 34 & 36 & 36 & 73 & 119 & 111 & 124 & 150 & 105 \\
\hline A2. New public sector loans on less favorable terms in 2008-2028 2 & 35 & 32 & 22 & 21 & 21 & 20 & 17 & 17 & 14 & 14 & 14 & 13 \\
\hline \multicolumn{13}{|l|}{ B. Bound Tests } \\
\hline B1. Real GDP growth at historical average minus one standard deviation in 2009-2010 & 35 & 32 & 22 & 21 & 21 & 20 & & 16 & 13 & 13 & 13 & 12 \\
\hline $\begin{array}{l}\text { B2. Export value growth at historical average minus one standard deviation in 2009-2010 3/ } \\
\text { / }\end{array}$ & 35 & 69 & 195 & 201 & 213 & 218 & 168 & 165 & 133 & 132 & 130 & 64 \\
\hline B3. US dollar GDP deflator at historical average minus one standard deviation in 2009-2010 & 35 & 32 & 22 & 21 & 21 & 20 & 16 & 16 & 13 & 13 & 13 & 12 \\
\hline B4. Net non-debt creating flows at historical average minus one standard deviation in 2009-2010 4/ & 35 & 65 & 63 & 64 & 68 & 69 & 53 & 52 & 42 & 42 & 41 & 21 \\
\hline B5. Combination of B1-B4 using one-half standard deviation shocks & 35 & 78 & 160 & 166 & 176 & 181 & 139 & 137 & 110 & 110 & 107 & 50 \\
\hline B6. One-time 30 percent nominal depreciation relative to the baseline in 20095 / & 35 & 32 & 22 & 21 & 21 & 20 & 16 & 16 & 13 & 13 & 13 & 12 \\
\hline \multicolumn{13}{|c|}{$\mathrm{PV}$ of debt-to-revenue ratio } \\
\hline Baseline & 63 & 56 & 51 & 46 & 42 & 37 & 34 & 32 & 30 & 29 & 28 & 17 \\
\hline \multicolumn{13}{|l|}{ A. Alternative Scenarios } \\
\hline A1. Key variables at their historical averages in 2008-2028 1/ & 63 & 63 & 73 & 73 & 70 & 66 & 157 & 247 & 266 & 285 & 328 & 156 \\
\hline A2. New public sector loans on less favorable terms in 2008-2028 2 & 63 & 56 & 51 & 46 & 42 & 37 & 36 & 35 & 33 & 32 & 30 & 20 \\
\hline \multicolumn{13}{|l|}{ B. Bound Tests } \\
\hline B1. Real GDP growth at historical average minus one standard deviation in 2009-2010 & 63 & 62 & 62 & 56 & 51 & 46 & 42 & 40 & 37 & 36 & 34 & 21 \\
\hline B2. Export value growth at historical average minus one standard deviation in 2009-2010 3/ & 63 & 87 & 177 & 171 & 166 & 159 & 143 & 136 & 127 & 120 & 112 & 37 \\
\hline B3. US dollar GDP deflator at historical average minus one standard deviation in 2009-2010 & 63 & 65 & 68 & 62 & 56 & 50 & 46 & 44 & 41 & 39 & 37 & 23 \\
\hline B4. Net non-debt creating flows at historical average minus one standard deviation in 2009-2010 4/ & 63 & 113 & 143 & 138 & 133 & 127 & 114 & 109 & 101 & 96 & 89 & 31 \\
\hline B5. Combination of B1-B4 using one-half standard deviation shocks & 63 & 139 & 284 & 276 & 269 & 259 & 232 & 221 & 205 & 195 & 181 & 58 \\
\hline B6. One-time 30 percent nominal depreciation relative to the baseline in 20095 / & 63 & 78 & 71 & 64 & 58 & 52 & 47 & 45 & 42 & 41 & 39 & 24 \\
\hline \multicolumn{13}{|c|}{ Debt service-to-exports ratio } \\
\hline Baseline & 2 & 3 & 2 & 2 & 2 & 2 & 2 & 1 & 1 & 1 & 1 & 0 \\
\hline A. Alternative Scenarios & & & & & & & & & & & & \\
\hline A1. Key variables at their historical averages in 2008-2028 1/ & 2 & 4 & 2 & 3 & 3 & 3 & 3 & 4 & 4 & 5 & 5 & 24 \\
\hline A2. New public sector loans on less favorable terms in 2008-2028 2 & 2 & 3 & 2 & 2 & 2 & 2 & 2 & 2 & 1 & 1 & 1 & 1 \\
\hline B. Bound Tests & & & & & & & & & & & & \\
\hline B1. Real GDP growth at historical average minus one standard deviation in 2009-2010 & 2 & 3 & 2 & 2 & 2 & 2 & 2 & 1 & 1 & 1 & 1 & 1 \\
\hline B2. Export value growth at historical average minus one standard deviation in 2009-2010 3/ & 2 & 4 & 6 & 10 & 10 & 10 & 8 & 7 & 6 & 5 & 7 & 8 \\
\hline B3. US dollar GDP deflator at historical average minus one standard deviation in 2009-2010 & 2 & 3 & 2 & 2 & 2 & 2 & 2 & 1 & 1 & 1 & 1 & 1 \\
\hline B4. Net non-debt creating flows at historical average minus one standard deviation in 2009-2010 4/ & 2 & 3 & 3 & 4 & 3 & 3 & 3 & 2 & 2 & 2 & 3 & 2 \\
\hline B5. Combination of B1-B4 using one-half standard deviation shocks & 2 & 4 & 5 & 8 & 8 & 8 & 6 & 6 & 4 & 4 & 6 & 6 \\
\hline B6. One-time 30 percent nominal depreciation relative to the baseline in 20095 / & 2 & 3 & 2 & 2 & 2 & 2 & 2 & 1 & 1 & 1 & 1 & 1 \\
\hline & service-to & venue & & & & & & & & & & \\
\hline Baseline & 4 & 6 & 5 & 5 & 4 & 4 & 3 & 3 & 3 & 2 & 2 & 0 \\
\hline A. Alternative Scenarios & & & & & & & & & & & & \\
\hline A1. Key variables at their historical averages in $2008-20281 /$ & 4 & 6 & 6 & 7 & 6 & 6 & 6 & 8 & 10 & 11 & 11 & 35 \\
\hline A2. New public sector loans on less favorable terms in 2008-2028 2 & 4 & 6 & 5 & 5 & 4 & 4 & 3 & 3 & 3 & 3 & 3 & 1 \\
\hline B. Bound Tests & & & & & & & & & & & & \\
\hline B1. Real GDP growth at historical average minus one standard deviation in 2009-2010 & 4 & 6 & 6 & 6 & 5 & 5 & 4 & 4 & 3 & 3 & 3 & 2 \\
\hline B2. Export value growth at historical average minus one standard deviation in 2009-2010 3/ & 4 & 6 & 6 & 9 & 8 & 7 & 6 & 6 & 5 & 5 & 6 & 4 \\
\hline B3. US dollar GDP deflator at historical average minus one standard deviation in 2009-2010 & 4 & 7 & 6 & 7 & 6 & 5 & 5 & 4 & 4 & 3 & 3 & 2 \\
\hline B4. Net non-debt creating flows at historical average minus one standard deviation in 2009-2010 4/ & 4 & 6 & 6 & 8 & 7 & 6 & 6 & 5 & 5 & 4 & 6 & 4 \\
\hline B5. Combination of B1-B4 using one-half standard deviation shocks & 4 & 7 & 9 & 13 & 12 & 11 & 10 & 9 & 8 & 7 & 10 & 7 \\
\hline B6. One-time 30 percent nominal depreciation relative to the baseline in 20095 / & 4 & 8 & 7 & 7 & 6 & 5 & 5 & 4 & 4 & 3 & 3 & 2 \\
\hline Memorandum item: & & & & & & & & & & & & \\
\hline Grant element assumed on residual financing (i.e., financing required above baseline) $6 /$ & 0 & 0 & 0 & 0 & 0 & 0 & 0 & 0 & 0 & 0 & 0 & 0 \\
\hline
\end{tabular}

Source: Staff projections and simulations.

1/ Variables include real GDP growth, growth of GDP deflator (in U.S. dollar terms), non-interest current account in percent of GDP, and non-debt creating flows. The DSA exercise was conducted jointly with the World Bank. 2/ Assumes that the interest rate on new borrowing is by 2 percentage points higher than in the baseline., while grace and maturity periods are the same as in the baseline.

3/ Exports values are assumed to remain permanently at the lower level, but the current account as a share of GDP is assumed to return to its baseline level after the shock (implicitly assuming

an offsetting adjustment in import levels).

$4 /$ Includes official and private transfers and FD

Depreciation is defined as percolloge decline in dollar/local currency rate, such that it never exceeds 100 percent.

6/ Applies to all stress scenarios except for A2 (less favorable financing) in which the terms on all new financing are as specified in footnote 2 
Table 4.Solomon Islands: Sensitivity Analysis for Key Indicators of Public Debt 2008-2028

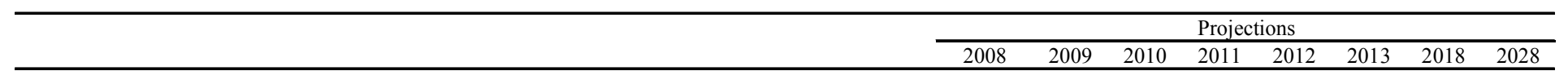

\section{PV of Debt-to-GDP Ratio}

Baseline

A. Alternative scenarios $1 /$

A1. Real GDP growth and primary balance are at historical averages

A2. Primary balance is unchanged from 2008

A3. Permanently lower GDP growth 2/

B. Bound tests

B1. Real GDP growth is at historical average minus one standard deviations in 2009-2010

B2. Primary balance is at historical average minus one standard deviations in 2009-2010

B3. Combination of B1-B2 using one half standard deviation shocks

B4. One-time 30 percent real depreciation in 2009

B5. 10 percent of GDP increase in other debt-creating flows in 2009

PV of Debt-to-Revenue Ratio 3/

Baseline

A. Alternative scenarios 1/

A1. Real GDP growth and primary balance are at historical averages

A2. Primary balance is unchanged from 2008

A3. Permanently lower GDP growth $2 /$

B. Bound tests

B1. Real GDP growth is at historical average minus one standard deviations in 2009-2010

B2. Primary balance is at historical average minus one standard deviations in 2009-2010

$\mathrm{B} 3$. Combination of $\mathrm{B} 1-\mathrm{B} 2$ using one half standard deviation shocks

B4. One-time 30 percent real depreciation in 2009

B5. 10 percent of GDP increase in other debt-creating flows in 2009

Debt Service-to-Revenue Ratio 3/

$\begin{array}{llllllll}32 & 28 & 25 & 21 & 19 & 17 & 12 & 7\end{array}$

$\begin{array}{llllllll}32 & 30 & 28 & 25 & \ldots & \ldots & \ldots & 157 \\ 32 & 33 & 34 & 35 & 37 & 39 & 64 & 106\end{array}$

$\begin{array}{llllllll}32 & 29 & 27 & 25 & 25 & 26 & 43 & 110\end{array}$

$\begin{array}{rrrrrrrr}32 & 35 & 41 & 44 & 47 & 52 & 74 & 104 \\ 32 & 36 & 42 & 38 & 35 & 33 & 26 & 15 \\ 32 & 35 & 38 & 39 & 41 & 43 & 49 & 46 \\ 32 & 37 & 34 & 30 & 27 & 25 & 17 & 7 \\ 32 & 37 & 34 & 31 & 28 & 26 & 20 & 11\end{array}$

$\begin{array}{lllllll}52 & 46 & 54 & 49 & 43 & 40 & 32\end{array}$

$\begin{array}{rrrrrrrr}52 & 48 & 59 & \ldots & \ldots & \ldots & \ldots & \ldots \\ 52 & 53 & 73 & 79 & 83 & 90 & 156 & 281 \\ 52 & 47 & 58 & 57 & 56 & 60 & 107 & 309\end{array}$

Baseline

A. Alternative scenarios 1/

A1. Real GDP growth and primary balance are at historical averages

A2. Primary balance is unchanged from 2008

A3. Permanently lower GDP growth 2/

$\begin{array}{rrrrrrrr}52 & 54 & 84 & 94 & 102 & 114 & 185 & 294 \\ 52 & 60 & 90 & 87 & 81 & 79 & 66 & 42 \\ 52 & 56 & 81 & 87 & 91 & 98 & 118 & 123 \\ 52 & 61 & 73 & 68 & 63 & 60 & 44 & 20 \\ 52 & 62 & 74 & 70 & 64 & 61 & 51 & 32\end{array}$

B. Bound tests

B1. Real GDP growth is at historical average minus one standard deviations in 2009-2010

B2. Primary balance is at historical average minus one standard deviations in 2009-2010

B3. Combination of B1-B2 using one half standard deviation shocks

B4. One-time 30 percent real depreciation in 2009

B5. 10 percent of GDP increase in other debt-creating flows in 2009

$\begin{array}{rrrrrrrr}4 & 5 & 5 & \ldots & \ldots & \ldots & \ldots & \ldots \\ 4 & 4 & 6 & 13 & 13 & 17 & 27 & 49 \\ 4 & 5 & 5 & 7 & 7 & 8 & 16 & 54\end{array}$

\begin{tabular}{rrrrrrrr}
4 & 5 & 6 & 13 & 17 & 20 & 32 & 50 \\
4 & 5 & 7 & 19 & 19 & 14 & 7 & 5 \\
4 & 5 & 7 & 14 & 14 & 18 & 19 & 19 \\
4 & 5 & 7 & 8 & 7 & 7 & 5 & 2 \\
4 & 5 & 7 & 18 & 7 & 13 & 5 & 3 \\
\hline
\end{tabular}

Sources: Country authorities; and Fund staff estimates and projections.

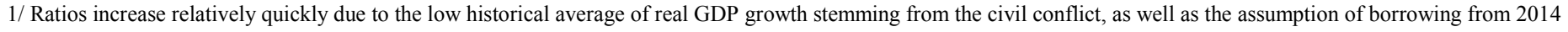
onwards.

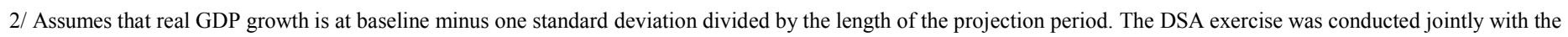
World Bank.

3/ Revenues are defined inclusive of grants. 
Figure 1. Solomon Islands: Indicators of Public and Publicly Guaranteed External Debt under Alternatives Scenarios, 2008-2028 1/
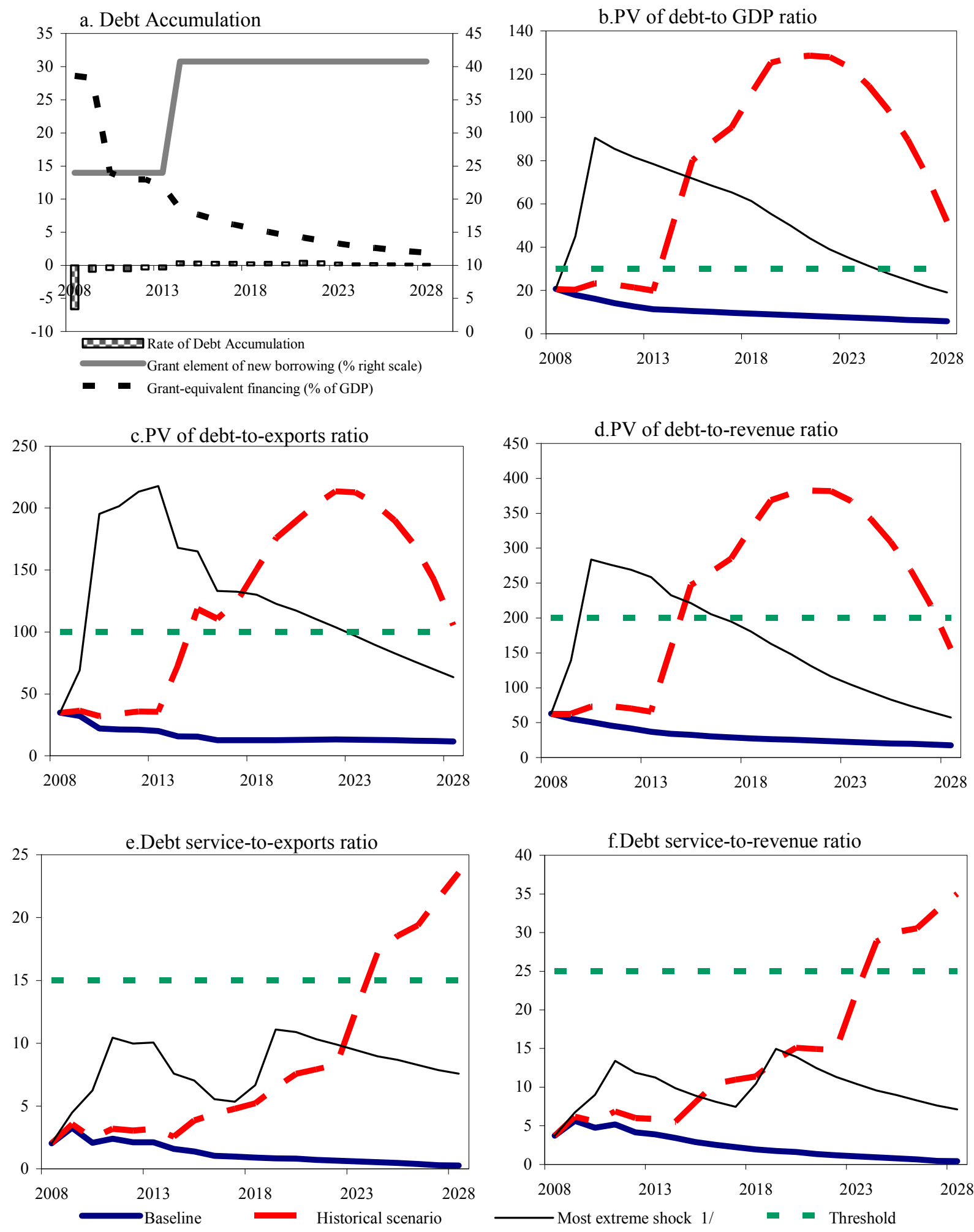

Source: Staff projections and simulations.

1/ The most extreme stress test is the test that yields the highest ratio in 2018. In figure b. it corresponds to a Combination shock; in c. to a Exports shock; in d. to a Combination shock; in e. to a Exports shock and in picture f. to a Combination shock 
Figure 2. Solomon Islands: Indicators of Public Debt Under Alternative Scenarios, 2008-2028 1/
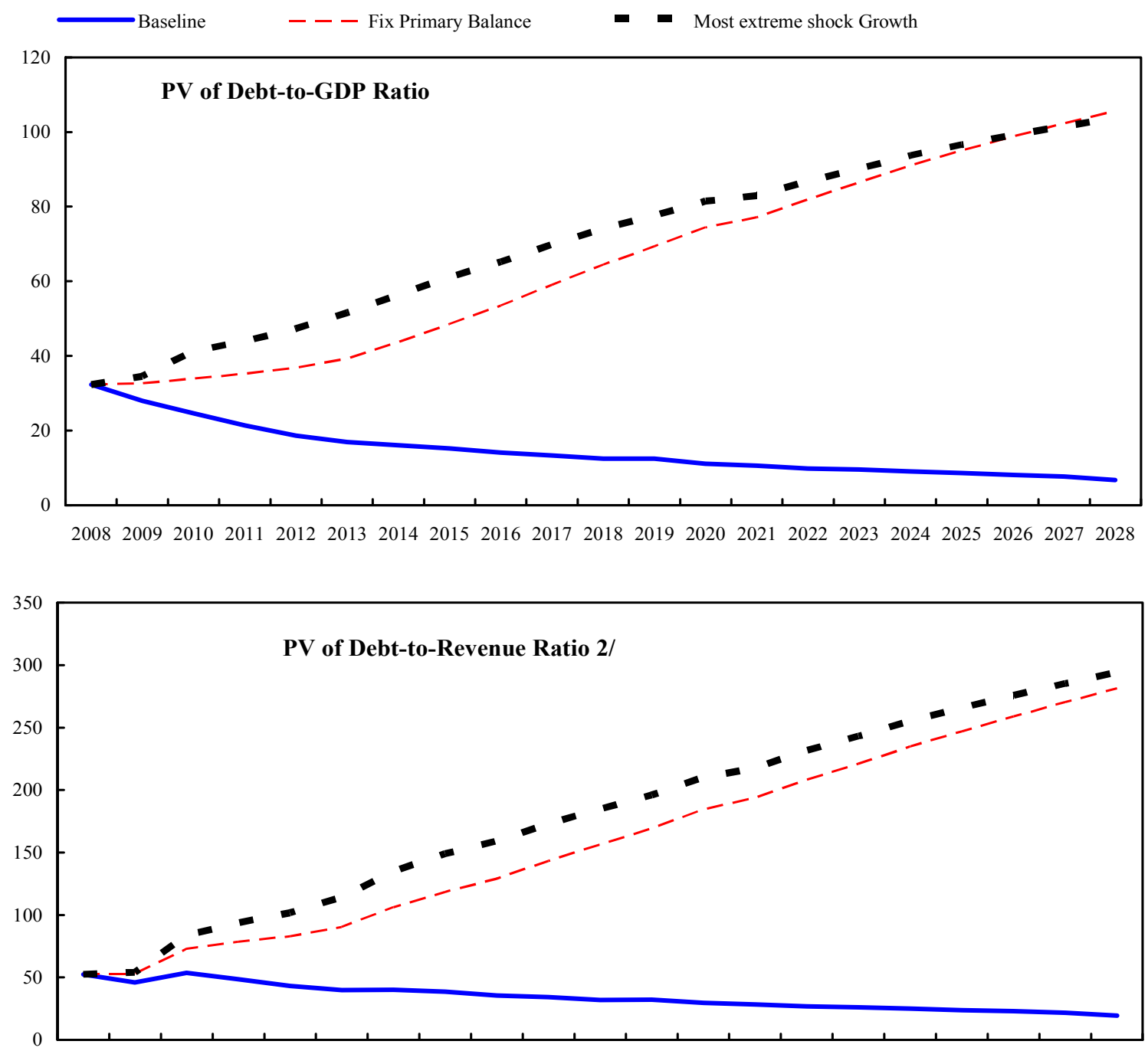

200820092010201120122013201420152016201720182019202020212022202320242025202620272028

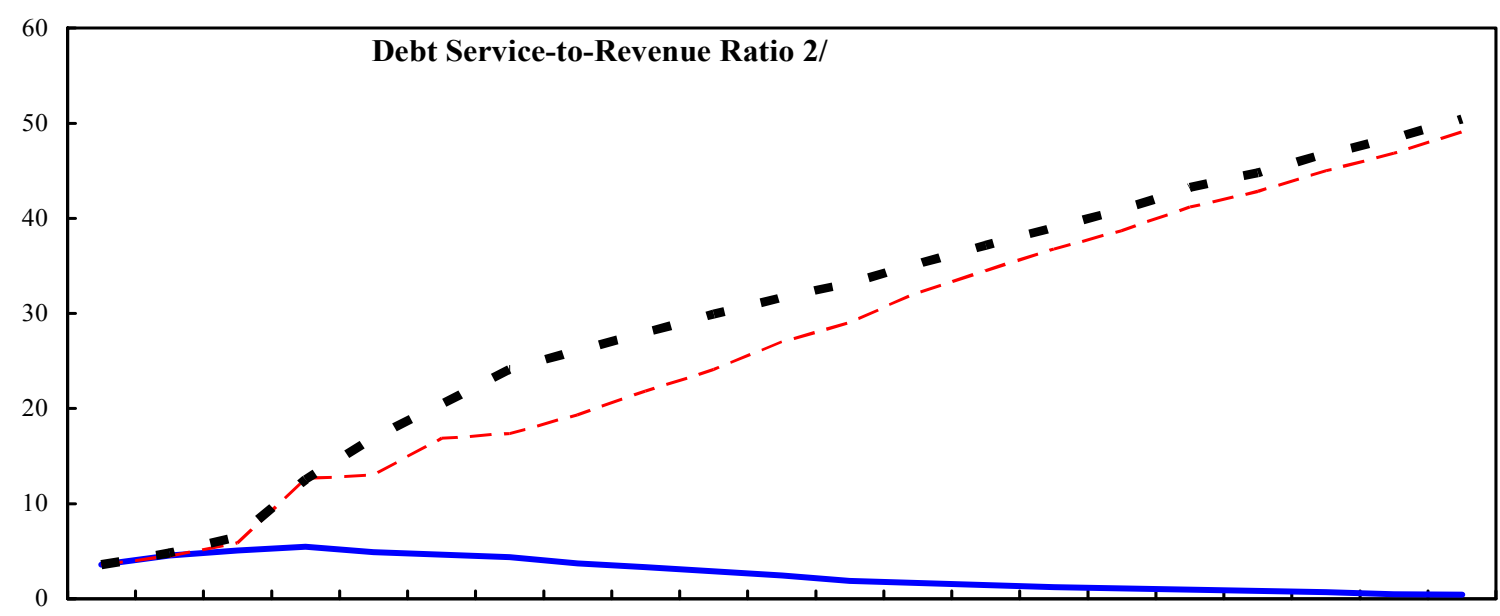

200820092010201120122013201420152016201720182019202020212022202320242025202620272028

Sources: Country authorities; and Fund staff estimates and projections.

$1 /$ The most extreme stress test is the test that yields the highest ratio in 2018.

2/ Revenues are defined inclusive of grants. 


\section{INTERNATIONAL MONETARY FUND \\ SOLOMON ISLANDS}

\section{Staff Report for the 2008 Article IV Consultation-Informational Annex}

Prepared by the Staff Representatives for the 2008 Consultation with Solomon Islands

(In consultation with other departments)

September 10, 2008

Contents

Page

I. The Authorities' Response to Recent Fund Policy Advice ..................................... 2

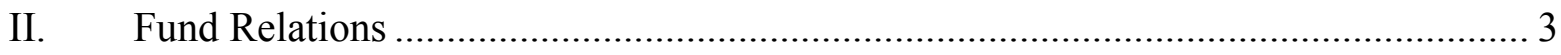

III. Support from the Pacific Financial Technical Assistance Center............................ 6

IV. Relations with the World Bank Group........................................................ 8

V. Relations with the Asian Development Bank …............................................... 11

VI. Poverty and Human Development Indicators ..................................................... 13

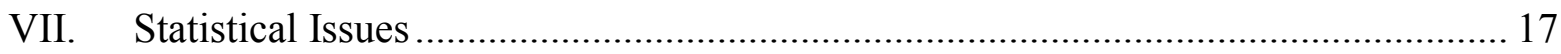




\section{ANNEX I: SOLOMON ISLANDS-THE AUTHORITIES' RESPONSE TO RECENT Fund Policy Advice}

\begin{tabular}{|c|c|}
\hline Advice from the 2007 Article IV Consultation & $\begin{array}{c}\text { Actions Taken } \\
\end{array}$ \\
\hline $\begin{array}{l}\text { Formulate a medium-term national development } \\
\text { strategy (NDS) }\end{array}$ & $\begin{array}{l}\text { The Ministry of Finance is currently consulting } \\
\text { with donors on a draft NDS. }\end{array}$ \\
\hline Formulate a medium-term budget framework & $\begin{array}{l}\text { Medium-term fiscal strategy prepared in February } \\
2008 .\end{array}$ \\
\hline $\begin{array}{l}\text { Save revenue overperformance and limit } \\
\text { expenditures to budgeted levels. }\end{array}$ & $\begin{array}{l}\text { Revenue overperformance was spent to finance } \\
\text { expenditures beyond budget levels. }\end{array}$ \\
\hline $\begin{array}{l}\text { Adjust the reference prices of logs and introduce an } \\
\text { automatic price adjustment mechanism. }\end{array}$ & $\begin{array}{l}\text { Reference prices were adjusted effective May } 1 \text {, } \\
\text { 2008. Planned additional increase in June } 2008 \\
\text { postponed to October 2008. An automatic price } \\
\text { adjustment mechanism has yet to be introduced. }\end{array}$ \\
\hline $\begin{array}{l}\text { Continue with preparations towards introducing a } \\
\text { VAT. }\end{array}$ & $\begin{array}{l}\text { The authorities have not yet decided on the exact } \\
\text { shape of the tax reforms they wish to introduce. }\end{array}$ \\
\hline $\begin{array}{l}\text { Enhance expenditure control through tighter payroll } \\
\text { controls and avoiding generalized civil service } \\
\text { wage increases. }\end{array}$ & $\begin{array}{l}\text { No tangible progress on recommendations from the } \\
\text { Special Audit Report on the Treasury Payroll. The } \\
\text { minimum wage was raised in April 2008, which } \\
\text { would require an increase in wages for some civil } \\
\text { servants. }\end{array}$ \\
\hline $\begin{array}{l}\text { Implementation of SIEA and SIWA management } \\
\text { contracts }\end{array}$ & $\begin{array}{l}\text { These were never implemented. The authorities' } \\
\text { strategy has changed. Current plans to strengthen } \\
\text { SIEA management include the hiring of external } \\
\text { managers with the assistance of WB. }\end{array}$ \\
\hline Privatize Solomon Airlines & No progress. \\
\hline Liquidate the DBSI & $\begin{array}{l}\text { No progress. The Central Bank's court-appointed } \\
\text { mandate to oversee DBSI has been extended to } \\
2009 \text {. }\end{array}$ \\
\hline Pass the NPF Bill & No progress. \\
\hline Continue to upgrade transport infrastructure & $\begin{array}{l}\text { ADB-supported projects to rehabilitate roads and } \\
\text { maritime services are on track and TA is being } \\
\text { provided to improve capacity at the Ministry of } \\
\text { Infrastructure and Development. }\end{array}$ \\
\hline Tighten prudential measures & $\begin{array}{l}\text { Basel I methodology for calculating risk weighted } \\
\text { assets was adopted and the capital adequacy ratio } \\
\text { increased in the fourth quarter } 2007 \text {. The } \\
\text { classification of banks' loan portfolios and } \\
\text { provisioning requirements were tightened in } \\
\text { December } 2007 \text {. }\end{array}$ \\
\hline Improve statistical database & $\begin{array}{l}\text { PFTAC has provided technical assistance on } \\
\text { improving external and national income accounts } \\
\text { statistics in 2008, but data quality and timeliness } \\
\text { remain poor. }\end{array}$ \\
\hline
\end{tabular}




\section{ANNEX II. SOLOMON ISLANDS-FUND RELATIONS}

(As of July 31, 2008)

I. Membership Status: Joined September 22, 1978; Article VIII

II. General Resources Account:

SDR Million

10.40

9.85

Fund holdings of currency

Reserve position in the Fund

III. SDR Department:

Net cumulative allocation

Holdings

0.55
SDR Million

0.65

0.01
Percent Quota

100.00

94.73

5.29

Percent Allocation

100.00

0.98

IV. Outstanding Purchases and Loans: None

V. Latest Financial Arrangements:

$\begin{array}{lcccc}\text { Type } & \begin{array}{c}\text { Approval } \\ \text { Date }\end{array} & \begin{array}{c}\text { Expiration } \\ \text { Date }\end{array} & \begin{array}{c}\text { Amount Approved } \\ \text { (SDR Mission) }\end{array} & \begin{array}{c}\text { Amount Drawn } \\ \text { (SDR Million) }\end{array} \\ \text { Stand-by } & 6 / 22 / 1983 & 6 / 21 / 1984 & 2.40 & 0.96\end{array}$

VI. Projected Payments to Fund:

(SDR Million; based on existing use of resources and present holdings of SDRs):

\begin{tabular}{lrrrrl} 
& \multicolumn{5}{c}{ Forthcoming } \\
& $\mathbf{2 0 0 8}$ & $\mathbf{2 0 0 9}$ & $\mathbf{2 0 1 0}$ & $\mathbf{2 0 1 1}$ & $\mathbf{2 0 1 2}$ \\
Charges/Interest & 0.01 & 0.02 & 0.02 & 0.02 & 0.02 \\
Total & 0.01 & 0.02 & 0.02 & 0.02 & 0.02
\end{tabular}

VII. Implementation of HIPC Initiative: Not applicable.

VIII. Implementation of MDRI Assistance: Not applicable.

\section{Exchange Rate Arrangements:}

Since November 2000, the exchange rate for the Solomon Islands (SI) dollar has been based on an undisclosed trade-weighted basket of the currencies of the Solomon Islands' major trading partners, with the U.S. dollar as the intervention currency. During 2002, as pressures on external reserves intensified, the Central Bank of Solomon Islands (CBSI) accelerated the rate of currency depreciation, leading to a gradual real depreciation of the SI dollar. Since December 2002, the CBSI has kept the exchange rate broadly stable against the U.S. dollar, although there is no public commitment to continue to do so. The Solomon Islands now 
maintains an exchange system that is free of restrictions on the making of payments and transfers for current international transactions.

\section{Last Article IV Consultation:}

The 2007 Article IV Consultation discussions were held in Honiara during May 11-22, 2007. The staff report was considered by the Executive Board and the consultation concluded on July 16, 2007.

XI. Technical Assistance:

Date

\section{Short-term}

January 14, 1998

February 3, 1998

May 4, 1998

June 7, 1998

June 30, 1998

November 28, 1998

February 9, 1999

September, 1999

October 3, 2000

May, 2001

October 2002

January 2003

February 2004

May 2004

September 2004

January 2005

February 2005

April 2005

May 2005

May 2005

August 2005

August 2005

August 2005

September 2005

October 2005

October 2005

November 2005

January 2006

January 2006

February 2006

February 2006

February 2006

April 2006

April 2006

May 2006

\section{Department Purpose}

PFTAC Statistics

PFTAC Tax administration

PFTAC Tax administration

PFTAC Banking supervision

PFTAC Balance of payments statistics

PFTAC Public financial management

PFTAC Banking supervision

MAE

MAE

PFTAC

PFTAC

PFTAC

PFTAC

PFTAC

MFD

PFTAC

PFTAC

PFTAC

MFD

PFTAC

MFD

MFD

PFTAC

PFTAC

LEG

MFD

STA

PFTAC

LEG

PFTAC

MFD

PFTAC

PFTAC

MFD

PFTAC
Treasury bill auctions and monetary operations

Advisor to CBSI

Banking supervision

Banking Supervision

Statistics

Statistics

Tax and customs administration

AML/CFT

Financial reporting system

Financial supervision of insurance

Financial supervision

Financial supervision of insurance

Tax policy and administration

Reserve management

Financial supervision of insurance

Statistics

AML/CFT

AML/CFT

Financial supervision of insurance

Monetary and Financial Statistics

Tax policy

Tax policy

AML/CFT

Financial supervision of insurance

Statistics

Statistics

Central Bank Accounting

Public Financial Management
Duration

2 weeks

1 week

4 weeks

2 weeks

2 weeks

1 week

1 week

8 weeks

2 weeks

1 week

10 days

1 week

2 weeks

2 weeks

1 week

2 weeks

2 weeks

2 weeks

2 weeks

2 weeks

2 weeks

4 weeks

2 weeks

2 weeks

4 days

4 weeks

3 weeks

2 weeks

2 weeks

2 days

4 weeks

2 weeks

2 weeks

3 weeks

2 weeks 


\begin{tabular}{|c|c|c|}
\hline June 2006 & MFD & Central Bank Accounting \\
\hline August 2006 & PFTAC & Public Accounting Procedures \\
\hline August 2006 & PFTAC & Public Expenditure Management \\
\hline October 2006 & $\mathrm{MCM}$ & TA program monitoring \\
\hline October 2006 & MCM & Financial sector supervision \\
\hline October 2006 & MCM & Reserve Management \\
\hline October 2006 & PFTAC & Budget and Public Expenditure Mgt \\
\hline December 2006 & PFTAC & Business Revenue Reform \\
\hline February 2007 & PFTAC & Balance of Payments Statistics \\
\hline February 2007 & PFTAC & National Income Accounts \\
\hline March 2007 & MCM & Accounting \\
\hline July 2007 & STA & Monetary and Financial Statistics \\
\hline November 2007 & PFTAC & National Income Accounts \\
\hline Feb-March 2008 & PFTAC & Tax Policy \\
\hline March-April 2008 & $\mathrm{MCM}$ & Accounting \\
\hline March 2008 & FAD & Tax Policy \\
\hline April 2008 & PFTAC & Balance of Payments Statistics \\
\hline May 2008 & PFTAC & National Income Accounts \\
\hline June 2008 & LEG & Review of Central Bank Act \\
\hline June 2008 & MCM & Monetary Operations \\
\hline July-August 2008 & STA & Money and Banking Statistics \\
\hline \multicolumn{3}{|l|}{ Long-term } \\
\hline June 1995-June 1999; & MAE & Advisor to CBSI Governor \\
\hline Jan. 2001-March 2008 & MFD & $\begin{array}{l}\text { Peripatetic Advisor to CBSI } \\
\text { Governor }\end{array}$ \\
\hline August 2006-Jan 2007 & PFTAC & Public Financial Management \\
\hline February 2008-2009 & STA & $\begin{array}{l}\text { Import Price Index } \\
\text { Statistics }\end{array}$ \\
\hline April 2008-2009 & MFD & $\begin{array}{l}\text { Peripatetic Advisor to CBSI } \\
\text { Governor }\end{array}$ \\
\hline
\end{tabular}

2 weeks

4 days

3 weeks

2 weeks

3 weeks

3 weeks

1 week

$11 / 2$ weeks

3 weeks

3 weeks

2 weeks

2 weeks

2 weeks

1 week

2 weeks

1 week

2 weeks

2 weeks

2 weeks

2 weeks

2 weeks

Five years extended in October 1999 through 2000.

Ten six-week missions

12 weeks in five months

[eight one-week missions]

Three 4-6 week missions

\section{Resident Representative: None}




\section{ANNEX III: SOLOMON ISLANDS-SUPPORT From THE PACIFIC FinANCIAL TECHNICAL ASSISTANCE CEnTER ${ }^{1}$}

(As of June 2008)

\section{Tax Administration and Policy}

A mission in May 2004 designed plans to modernize and enhance the efficiency of the Customs and Tax Divisions. A further mission in May 2005 reviewed the current system, outlined a detailed strategy for the implementation of tax reforms over the next few years, and assessed the required technical assistance to support this strategy. The authorities released a tax reform proposal in conformity with PFTAC's advice. A mission in February 2006 assisted the government further with a detailed implementation plan, including discussions on the policy and design issues in relation to the VAT, income tax and revenue administration. With assistance from LEG, draft legislation was prepared for the VAT and Revenue Administration Acts. In December 2006, a mission assisted the authorities in the preparation of a high-level design and project plan for the implementation of the Business Revenue Reform, and a follow-up visit took place in early May 2007. A joint FAD-PFTAC regional mission took place in February-March 2008 and recommended strategies for addressing future revenue needs, and a follow up visit took place in May 2008. However, the government's revenue policy remains to be finalized.

\section{Public Financial Management}

In May 2006, the PFTAC adviser undertook a review of the Public Finance and Audit Act (PFAA; 1978), the Financial Instructions (FI; 1978) and the Stores Instructions (1976; SIs). The mission agreed with the authorities that the more immediate need was for a process redesign of the key accounting operations, linked to a significant redraft of the FI. In August 2006, a mission recommended measures to improve accounting operations and installed two consultants to redraft the FI. A final report was sent to the authorities in January 2007. The government has indicated that their new AUSDAID/RAMSI advisor will review this in consultation with PFTAC.

\footnotetext{
${ }^{1}$ The Pacific Financial Technical Assistance Centre (PFTAC) in Suva, Fiji, is a regional technical assistance institution operated by the IMF with financial support of the Asian Development Bank, Australia, Japan, Korea, and New Zealand. The Center's aim is to build skills and institutional capacity for effective economic and financial management that can be sustained at the national level. Member countries are: Cook Islands, Federated States of Micronesia, Fiji, Kiribati, Marshall Islands, Nauru, Niue, Palau, Papua New Guinea, Samoa, Solomon Islands, Tokelau, Tonga, Tuvalu, and Vanuatu.
} 


\section{Financial Sector Regulation and Supervision}

In September 2004, an advisor visited the CBSI to advise on the implementation of an antimoney laundering regime. A peripatetic advisor visited in January 2005 to assist with improving the CBSI's bank supervision department's database. In April 2005, the PFTAC advisor worked with an MCM expert to provide assistance in dealing with a failed insurance company and developing a supervisory framework for insurance companies, provided advice on the oversight of the National Provident Fund, developed supervisory guidelines on AML/CFT activities in financial institutions, and prepared a project document for the establishment of the Financial Intelligence Unit (FIU). In September 2005, the PFTAC advisor assisted CBSI staff in conducting an AML/CFT on-site examination of a domestic bank. CBSI staff also attended a seminar on monetary policy in shallow markets arranged by PFTAC/MFD in March 2005. In February 2006, the advisor participated in an AML/CFT awareness training seminar conducted by the CBSI. In November 2006, the CBSI hosted the annual meeting of the Association of the Financial Supervisors of Pacific Countries. [A mission in May 2008 provided training to CBSI staff on implementing Basel I and the use of regulatory reporting forms.]

\section{Economic and Financial Statistics}

During 2003, the National Statistics Office (NSO) restarted activity, with the production of the Honiara CPI. A joint PFTAC/Secretariat of the Pacific Community mission in February 2004 devised a recovery plan, and AusAID and NZAID provided funding for equipment and a long-term advisor (a former PNG deputy statistician) to help build capacity and also to coordinate the Household Income and Expenditure Survey (HIES). The CBSI compiles balance of payments and GDP data and CBSI staff attended a regional training course on balance of payments statistics arranged by PFTAC in April 2005. Missions in August 2005 and February 2006 reviewed current methodologies for balance of payments and national accounts statistics and suggested some short-term improvements to their compilation. Assistance was also provided on a prototype government finance statistics system. In September 2006, the NSO released the findings of the 2005/06 HIES. In July 2007, a Monetary and Financial Statistics mission visited to assist the authorities in moving towards the MFSM 2000 reporting standards. Over the February 2007-May 2008 period, PFTAC experts assisted the authorities in improving the compilation of balance of payments statistics and revising the GDP data. Future follow up missions include a CPI rebase and import price index mission in August-September 2008 and a BOP and IIP statistics mission in early 2009.

Contact person: Susan Adams, Project Coordinator, sadams@imf.org. 


\section{ANNEX IV: SOLOMON ISLANDS-RELATIONS WITH THE WORLD BANK GROUP}

(As of June 2008)

Since becoming a Bank member in June 1978, the Solomon Islands has received eight IDA credits totaling US\$50 million in the infrastructure, education, health, finance, and agriculture sectors. Following the repayment of all outstanding arrears in September 2003, the Solomon Islands came out of nonaccrual status, and country relations have normalized. The Solomon Islands is eligible for an IDA 14 allocation of SDR 7.3 million (indicative only) over FY 2006-08. The IDA allocation for FY 07 is SDR 5.2 million.

The Bank's assistance to the Solomon Islands is motivated by the need for re-engagement in a low capacity post-conflict country, while recognizing the abundance of donor funds. The assistance program is guided by the government's own development priorities articulated in the National Economic Reform, Recovery, and Development Plan (2003-06), and the Bank's broader Pacific Regional Engagement Framework (2005-2009) which has a focus on (i) strengthening government capabilities, and (ii) improving incentives for the private sector. The Bank's involvement in the Solomon Islands is in the following areas:

\section{Strengthening Government Capabilities}

- Health Sector: The government has initiated preparatory steps to move toward a sectorwide approach (SWAp) in the health sector, consistent with the direction that AusAID, as main donor to the sector, is also moving as indicated in the recent AusAID's White Paper on development aid. IDA approved the Health Sector Support Program Technical Assistance Project worth SDR 1.0 million (US\$1.5 million) in March 2008, which will focus on improving public expenditure management, monitoring performance, and building management capacity.

- Education SWAp: The Bank has co-financed a study to support the development of a National Skills Training Plan. The government has yet to decide on joining the Education for All Fast Track Initiative (FTI). The Bank is not planning any other major operations in the education sector at this stage.

Energy Supply: The Bank is supporting the government's decision to implement a structural reform program in the electricity sector in order to improve electricity supplies, reduce their dependence on diesel-fired electricity generation, and provide affordable rural electricity systems. The government has determined that the best way to improve the performance of the Solomon Islands Electricity Authority (SIEA) is to improve operational efficiency, system reliability and financial sustainability of SIEA through: improved financial and operational management, reduction of losses, improved generator and distribution system reliability and improved revenue collection. IDA and RAMSI will support the Government 
by making available an IDA grant to finance the following project components:

Strengthening Management. Engagement of two expatriate line managers (an expatriate General Manager with a technical background and a Commercialization Manager) and an overseas Director to be appointed to the Board; Financial Operations. Implementation of a commercialization program for the Finance Department, including new financial management and billing systems and preparation and implementation of a new finance accounting manual with a staff training program, and Technical Operations.

Implementation of a loss reduction program, a planned maintenance program for generation facilities in Honiara, and a distribution reinforcement program to increase the availability of existing generation and improve system reliability. Technical project implementation support to SIEA will also be provided, with consultancy services, a technical training program for engineering staff, and establishment of a partnership with the Fiji Electricity Authority. The project is scheduled for World Bank Board approval by June 17, 2008. In preparation for the implementation of the project, the Government has approved a debt restructuring and cross liability adjustment scheme where the SIG will forgive SBD 196.0 million in on-lent loans and SBD 8.5 million in Pay-as-you-earn taxes (PAYE) and custom duties arrears in return for the SIEA to write off SBD 21 million in SOE and arrears of other government authorities, for a net total contribution of SBD 183.5 million (US\$25.8 million). In addition, the Government will provide a cash contribution to SIEA of SBD 5 million (US\$0.7 million) exemption of duties and taxes on goods and services financed through the project for a total of US\$1.65 million. Based on the debt restructuring and the proposed project, the Bank expects that by 2011, SIEA will be in a position to pay taxes and still be profitable. The GEF supported regional renewable energy and energy efficiency project has now started operations in Solomon Islands, two of the major commercial banks are now offering long term loans for SolarPV equipment, making these accessible to a majority of the population.

Water Sector: The Bank has prepared a Financial Restructuring Plan (FRP) for the Solomon Islands Water Authority (SIWA). The report provides the government and SIWA Board with an overview of SIWA's financial position and recommends that the management contract for the SIEA be extended to cover SIWA. JICA has started to implement a technical restructuring plan at a cost of US\$9 million to be completed in three years time.

- Rural Growth: The Bank has completed the Agriculture and Rural Development Strategy (ARDS) which has been disseminated within the country. The Bank launched the Solomon Islands Rural Development Program (RDP) in February 2008, co-financed by the EU and RAMSI, and implements the main recommendations of the ARDS. Implementation started for four provinces and is scheduled to start in 2010 for the remaining provinces. 


\section{Improving Incentives for the Private Sector}

- Telecommunications Sector: The Bank is providing grant-funded technical assistance to the government to examine ways to improve the competitiveness of the sector to reduce telecommunication costs and improve service quality and coverage, in particular outside Honiara. Specifically, the Bank is advising the government on: (a) strategic options for reform, including market liberalization/introduction of competition; (b) preparation of a new telecommunication law; and (c) development of new sector regulations including for rural/universal access. The Bank is ready to assist the government to manage the transition from a monopoly to competition if the Cabinet chooses to renegotiate the current 15-year exclusive license of the incumbent, Our Telekom, on the occasion of the first period review in 2008; and if management of Our Telekom is willing to renegotiate the exclusive license. The Bank is also ready to consider a longer-term program of technical support - possibly through an IDA grant if the government wishes-for development of regulatory capacity and a rural access program.

- Foreign and Domestic Investment: The Foreign Investment Advisory Service (FIAS) has provided assistance to the government for the preparation of new foreign investment legislation and with a review of investment incentives and administrative barriers to business. Preliminary discussions with the Government on the participation of Solomon Islands in the WBG Pacific Regulatory Simplification and Investment Policy and Promotion Program are ongoing. 


\section{ANNEX V: SOLOMON ISLANDS-RELATIONS WITH THE ASIAN DEVELOPMENT BANK}

(As of June 2008)

Since joining AsDB in 1973, Solomon Islands has received 16 loans amounting to $\$ 79.3$ million, and 58 technical assistance (TA) projects amounting to \$13.85 million. Solomon Islands is eligible for the Asian Development Fund (ADF) grants available to countries that are very poor, heavily indebted, or in a post-conflict situation. AsDB approved ADF grant in the amount of \$350,000 in 2006 and \$4.95 million in 2007. The 2005-06 and 2006-2008 ADF allocations for Solomon Islands succeeded in catalyzing substantial bilateral grant cofinancing for the improvement of rural roads and wharves (an additional \$16.5 million in cofinancing from Australia and New Zealand and an additional \$4 million in cofinancing from the European Commission).

AsDB's country assistance strategy seeks to achieve rapid, pro-poor, private sector-led economic growth, and focuses on improving transportation infrastructure and services and the enabling business environment. ${ }^{2}$ Capacity development and the promotion of good governance are priorities. AsDB assistance is currently provided entirely on a grant basis and, in line with government policy, no new lending to the country will be provided until public finances stabilize.

AsDB has committed substantial support through an ADF grant funded Emergency Assistance Project to the country in response to a strong earthquake and consequent tsunami on April 2, 2007, which caused significant damage in Choiseul and Western Provinces. The project will include the repair of priority unsealed roads and watercourse crossings; replacement of bridges; reconstruction of wharves and jetties; and reconstruction of the Gizo town water supply and sanitation system.

AsDB currently has ongoing TA projects in the areas of institutional strengthening of the Ministry of Infrastructure and Development, inter-island transportation, private sector participation, business law reform, and secured transactions reform. AsDB's Post-conflict Emergency Rehabilitation Project, which helped rehabilitate about $140 \mathrm{~km}$ of roads and 51 bridges on Guadalcanal and Malaita damaged during the civil conflict (1999-2002) was completed on 31 March 2008. The Solomon Islands Road Improvement Project, approved in 2006 as an ADF grant with significant bilateral grant cofinancing, helps to rehabilitate roads and bridges throughout the country to improve rural residents' access to markets and economic and social services, promote private sector-led development, foster market

\footnotetext{
2 The Country Strategy and Program Update 2007-09 can be found at www.adb.org/Documents/CSPs/SOL/2006, and the Country Operations Business Plan 2008-2010 at http://www.adb.org/Documents/CSPs/SOL/2007/COBP-SOL-2007.pdf.
} 
formation, and facilitate domestic and international trade and income and employment opportunities.

AsDB's Pacific Liaison and Coordination Office in Sydney is responsible for country programming, project implementation and administration, supported by the Pacific Operations Division in Manila.

Loans, Approvals, and Disbursements, 1999-2007

(In millions of U.S. dollars)

\begin{tabular}{|c|c|c|c|c|c|c|c|c|c|}
\hline & 1999 & 2000 & 2001 & 2002 & 2003 & 2004 & 2005 & 2006 & 2007 \\
\hline Loan approvals & -- & 10.00 & -- & -- & -- & -- & -- & -- & -- \\
\hline Loan disbursements & 0.00 & 0.00 & 0.00 & 0.00 & 0.00 & 0.89 & 2.76 & 4.09 & 3.75 \\
\hline $\begin{array}{l}\text { Cumulative loan amount } \\
\text { approved } \\
\text { (as of end-of-year) }\end{array}$ & 69.31 & 79.31 & 79.31 & 79.31 & 79.31 & 79.31 & 79.31 & 79.31 & 79.31 \\
\hline $\begin{array}{l}\text { Cumulative net effective } \\
\text { loans } \\
\text { (as of end-of-year) }\end{array}$ & 64.65 & 54.30 & 64.05 & 64.83 & 65.87 & 66.31 & 79.31 & 79.31 & 79.31 \\
\hline $\begin{array}{l}\text { Cumulative disbursements } \\
\text { (as of end-of-year) }\end{array}$ & 53.61 & 54.07 & 54.07 & 54.07 & 54.30 & 55.16 & 57.91 & 62.00 & 65.75 \\
\hline
\end{tabular}

Contact person: Winfried Wicklein, Country Team Leader for Solomon Islands, AsDB Sydney (wwicklein@adb.org). 


\section{ANNEX VI: SOLOMON ISLANDS-POVERTY AND HuMAN DEVELOPMENT INDICATORS}

Social indicators of poverty and human development remain low in the Solomon Islands. The country ranks 129 out of 177 countries in the 2007/08 United Nations Human Development Index, below all Pacific island countries, except Papua New Guinea. There are few recent poverty statistics, but anecdotal evidence suggests poverty remains high. However, the more extreme forms of poverty, such as malnourishment, have remained limited due to an abundant resource base, assured access to customary land tenure, and resilient social networks. This advantage is under pressure from a population growth rate that, at about 3 percent a year, is among the highest in the world. ${ }^{3}$

Results of the 2005-06 HIES indicate that majority of the population do not have access to basic services such as electricity and water. For example, 86 percent of the population uses open fire for cooking, 80 percent relies on kerosene lamps as primary source of energy, and 78 percent does not have water piped into their household.

Nonetheless, the Solomon Islands has achieved some progress in improving living conditions since independence despite falling per capita incomes. Prior to the civil conflict in 1999, sizable health and education expenditures (at 3-5 percent of GDP each) and high per capita aid inflows had helped underpin these improvements. Providing widespread and quality education to the very young population (45 percent under age 15) is a challenge. The primary education enrollment ratio is about 95 percent, although primary education is not compulsory. The enrollment ratio is only 30 percent in secondary education. Concerning health, malaria is rampant, with the highest rate of infection in the world outside of subSaharan Africa, and a third of the rural population lacks access to safe water.

The paucity of data makes an assessment of human development trends since 1999 difficult, but anecdotal evidence suggests that pro-poor services delivery is improving. The positive trend was likely either halted or reversed during the civil conflict. While the conflict sharply reduced agricultural production for market (due to the lack of security and transport services), this has recovered since mid-2003 and service delivery has been enhanced.

The aggregate social indicators mask large differences between urban and rural areas. The two main problems in the rural sector are the lack of essential public services such as health and education, and cash income due to difficulties in market access for rural products. While the urban areas have better social services and average incomes are higher, the urban poor face difficulties in securing employment and land for residence.

\footnotetext{
${ }^{3}$ The 2005-06 HIES estimates the average population growth rate at 4.4 percent, but the authorities are disputing this.
} 
The government has committed to monitor progress towards the Millennium Development Goals (MDGs). Achieving the MDGs by 2015 is still possible, but remains a major challenge. Progress in some areas, such as reducing malaria incidence, maternal mortality, and ensuring environmental sustainability, has so far been inadequate. 


\section{Table VI.1. Solomon Islands: Millennium Development Goals Progress}

\begin{tabular}{|c|c|c|c|c|}
\hline & 1990 & 2000 & $\begin{array}{r}\text { Latest Data } \\
2003-06\end{array}$ & $\begin{array}{r}\text { Target } \\
2015\end{array}$ \\
\hline \multicolumn{5}{|l|}{ Goal 1: Eradicate Extreme Poverty and Hunger } \\
\hline Prevalence of child malnutrition (percent of children under 5) & 21 & 21 & 21 & 11 \\
\hline \multicolumn{5}{|l|}{ Goal 2: Achieve Universal Primary Education } \\
\hline Net enrollment ratio in primary education & 83 & 74 & 80 & 100 \\
\hline \multicolumn{5}{|l|}{ Goal 3: Promote Gender Equality } \\
\hline Ratio of girls to boys in primary school (percent) & 86 & 94 & 96 & 100 \\
\hline Ratio of girls to boys in secondary school (percent) & 63 & 79 & 84 & 100 \\
\hline Proportion of seats held by women in national parliament (percent) & 0 & 2 & 0 & $\ldots$ \\
\hline \multicolumn{5}{|l|}{ Goal 4: Reduce Child Mortality } \\
\hline Under 5 mortality rate (per 1,000$)$ & 121 & 88 & 73 & 12 \\
\hline Infant mortality rate (per 1,000 live births) & 86 & 65 & 55 & 25 \\
\hline \multicolumn{5}{|l|}{ Goal 5: Improve Maternal Health } \\
\hline Maternal mortality ratio (per 100,000 live births) & $\ldots$ & 130 & 220 & ... \\
\hline Births attended by skilled health staff (percent of total) & $\ldots$ & 85 & $\ldots$ & $\ldots$ \\
\hline \multicolumn{5}{|l|}{ Goal 6: Combat HIVIAIDS, Malaria and Other Diseases } \\
\hline Incidence of tuberculosis (per 100,000 people) & 292 & 181 & 135 & \\
\hline Incidence of malaria (per 100,000 people) & 45,000 & 15,172 & 19,600 & less than 8000 \\
\hline \multicolumn{5}{|l|}{ Goal 7: Ensure Environmental Sustainability } \\
\hline Forest area (percent of total land area) & 99 & 91 & 78 & ... \\
\hline Nationally protected areas (percent of total land area) & $\ldots$ & 0 & 0.1 & $\ldots$ \\
\hline $\mathrm{CO} 2$ emissions (metric tons per capita) & 0.5 & 0.4 & 0.4 & $\ldots$ \\
\hline Access to an improved water source (percent of population) & $\ldots$ & 69 & 70 & 100 \\
\hline Access to improved sanitation (percent of population) & $\ldots$ & 31 & 31 & $\ldots$ \\
\hline \multicolumn{5}{|l|}{ Goal 8: Develop a Global Partnership for Development } \\
\hline Fixed line and mobile telephones (per 1,000 people) & 15 & 21 & 28 & $\ldots$ \\
\hline Personal computers (per 1,000 people) & $\ldots$ & 39 & 47 & $\ldots$ \\
\hline
\end{tabular}

Sources: World Bank, World Development Indicators and World Bank Human Development Indicators. 
Table VI.2. Solomon Islands: Social Indicators

\begin{tabular}{|c|c|c|c|c|c|c|c|}
\hline & \multicolumn{5}{|c|}{ Latest Single Year } & \multicolumn{2}{|c|}{ Same Region/Income Group } \\
\hline & $1970-75$ & $1980-85$ & 1990-95 & 1996-2005 & 2006-present & $\begin{array}{r}\text { East } \\
\text { Asia \& } \\
\text { Pacific }\end{array}$ & $\begin{array}{r}\text { Low- } \\
\text { Income }\end{array}$ \\
\hline \multicolumn{8}{|l|}{ POPULATION } \\
\hline Total population, mid-year (thousands) & 193 & 272 & 362 & 472 & 484 & $1,898,889$ & $2,419,656$ \\
\hline Growth rate & 3.6 & 3.2 & 2.8 & 2.5 & 2.4 & 0.8 & 1.8 \\
\hline Urban population (percent of population) & 9.1 & 12.4 & 15.0 & 16.8 & $\ldots$ & 40.6 & 12.0 \\
\hline Total fertility rate (births per woman) & 7.1 & 6.2 & 5.2 & 4.1 & 4.0 & 2.0 & 3.5 \\
\hline \multicolumn{8}{|l|}{ INCOME } \\
\hline GNI per capita (US\$) & 290 & 530 & 880 & 630 & 690 & 1,856 & 649 \\
\hline Consumer price index $(2000=100)$ & 8 & 20 & 63 & 148 & 159 & 138 & 145 \\
\hline Food price index $(1995=100)$ & $\ldots$ & 33 & $\ldots$ & 158 & $\ldots$ & $\ldots$ & $\ldots$ \\
\hline \multicolumn{8}{|l|}{ SOCIAL INDICATORS } \\
\hline \multicolumn{8}{|l|}{ Public expenditure } \\
\hline Health (percent of GDP) & $\ldots$ & $\ldots$ & $\ldots$ & 4.0 & $\ldots$ & 1.8 & 1.2 \\
\hline Education (percent of GDP) & 5.3 & 4.5 & 3.8 & 3.3 & $\ldots$ & 3.5 & 3.1 \\
\hline Social security and welfare (percent of GDP) & $\ldots$ & $\ldots$ & $\ldots$ & $\ldots$ & $\cdots$ & $\ldots$ & $\ldots$ \\
\hline \multicolumn{8}{|l|}{$\begin{array}{l}\text { Net primary school enrollment rate } \\
\text { (Percent of age group) }\end{array}$} \\
\hline Total & ... & $\ldots$ & $\ldots$ & 62 & $\ldots$ & 93 & 78 \\
\hline Male & $\ldots$ & $\ldots$ & $\ldots$ & 62 & $\ldots$ & 93 & 81 \\
\hline Female & $\ldots$ & $\ldots$ & $\ldots$ & 61 & $\ldots$ & 93 & 75 \\
\hline \multicolumn{8}{|l|}{$\begin{array}{l}\text { Access to an improved water source } \\
\text { (Percent of population) }\end{array}$} \\
\hline Total & $\ldots$ & $\ldots$ & 69 & 70 & $\ldots$ & 79 & 75 \\
\hline Urban & $\ldots$ & $\ldots$ & 94 & 94 & $\ldots$ & 92 & 88 \\
\hline Rural & $\ldots$ & $\ldots$ & 65 & 65 & $\ldots$ & 70 & 69 \\
\hline \multicolumn{8}{|l|}{$\begin{array}{l}\text { Immunization rate } 1 / \\
\text { (Percent } 12-23 \text { months) }\end{array}$} \\
\hline Measles & $\ldots$ & $\ldots$ & 68 & 70 & 84 & 89 & 69 \\
\hline DPT & $\ldots$ & 38 & 69 & 78 & 91 & 89 & 68 \\
\hline Child malnutrition (percent under 5 years) & 21 & $\ldots$ & 16 & $\ldots$ & $\ldots$ & 13 & 35 \\
\hline \multicolumn{8}{|l|}{$\begin{array}{l}\text { Life expectancy at birth } \\
\text { (Years) }\end{array}$} \\
\hline Total & 56 & 57 & 60 & 63 & 63 & 71 & 60 \\
\hline Male & 55 & 57 & 59 & 62 & 63 & 69 & 59 \\
\hline Female & 56 & 58 & 60 & 64 & 64 & 73 & 62 \\
\hline \multicolumn{8}{|l|}{ Mortality } \\
\hline Infant (per 1,000 live births) & 71 & 43 & 75 & 56 & 55 & 24 & 74 \\
\hline Under 5 (per 1,000 live births) & 99 & 56 & 103 & 75 & 73 & 29 & 112 \\
\hline \multicolumn{8}{|l|}{ Adult (15-59) } \\
\hline Male (per 1,000 population) & $\ldots$ & $\ldots$ & $\ldots$ & 240 & 238 & 165 & 285 \\
\hline Female (per 1,000 population) & $\ldots$ & $\ldots$ & $\ldots$ & 210 & 207 & 104 & 223 \\
\hline Maternal (modeled, per 100,000 live births) & $\ldots$ & $\ldots$ & $\ldots$ & 220 & $\ldots$ & 150 & 650 \\
\hline Births attended by skilled health staff (percent) & $\ldots$ & $\ldots$ & 85 & 85 & $\ldots$ & 87 & 43 \\
\hline
\end{tabular}

Source: World Bank, 2006 World Development Indicators.

$1 /$ Immunization refers to children aged 12-23 months who received vaccinations before one year of age. 


\section{ANNEX VII: SOLOMON ISLANDS-STATISTICAL ISSUES}

Data provision has serious shortcomings that significantly hamper surveillance, particularly for the real, fiscal, and external sectors. Although the National Statistics Office (NSO) is being rebuilt, the Central Bank of Solomon Islands (CBSI) continues to publish highly summarized monetary and price data in its Monthly Economic Bulletin and data on all sectors in its Quarterly Review and Annual Report. There is a Solomon Islands page in IFS, but significant updating delays occur, particularly for the balance of payments (BOP), government finance, and national accounts statistics.

\section{Real Sector Statistics}

GDP estimates are currently prepared by the CBSI. Despite several TA missions by PFTAC, GDP estimates remain severely hampered by data availability and quality, and rely on limited sources (primarily commodity exports and employment estimates). A survey of business activities for 2003 covering 1,434 businesses was published by the NSO in August 2006, including employment and financial data for NSO-registered private and government business enterprises. A 2005-06 Household Income and Expenditure Survey (HIES) was completed in September 2006. Data on production of major export commodities are reported monthly. No breakdown of GDP by expenditure categories exists.

GDP was rebased to 2004 with the help of a PFTAC advisor in February 2007. More recently, the May 2008 PFTAC mission provided further assistance in finalizing the 2003 and 2004 National Account estimates, as well as developing preliminary estimates for 2005 and 2006.

The NSO produces the CPI, which currently covers only the capital Honiara. Using the HIES results, the weights of the Honiara price index were revised in 2007; and the authorities plan to compile a national CPI measure, which will initially cover major provinces in the near future. To this end, the NSO has already constructed a list of commodities to be covered by weight, but the collection of actual price data has yet to commence. Limited data on total employment can be obtained from the National Provident Fund. Wage data are not compiled. The Ministry of Tourism, in coordination with NSO, has launched a visitors' survey in early 2008 to measure tourism spending.

\section{Monetary and Financial Statistics (MFS)}

The CBSI publishes monthly MFS in summary form and provides more detailed data in its quarterly and annual reports. Reporting of monetary statistics to the Fund has improved recently, but still has a lag of about two months. A November 2005 expert mission, during a PFTAC monetary statistics workshop held in Fiji, reviewed the collection and compilation procedures and provided training and a work plan for the CBSI to comply with the 
methodology of the Monetary and Financial Statistics Manual and to report data using the standardized report forms (SRFs). A July 2007 mission found that limited progress had been made in implementing the 2005 mission's recommendations due to the high turnover rate of the CBSI's monetary statistics team. The mission introduced the SRF for the central bank, and initiated the development of an integrated monetary database that will meet the data needs of the CBSI and the Fund. A follow-up mission is scheduled for early 2009 to introduce the SRF for the other depository corporations based on a soon to be introduced call report form to collect balance-sheet data from reporting corporations.

\section{Government Finance Statistics (GFS)}

The Ministry of Finance (MOF) started monthly press releases on budget outturns in August 2003. However, its expenditure and financing data are not consistent with the GFSM 2001 methodology, and historical data seem unreliable given the breakdown of accounting mechanisms and large expenditure arrears. The NSO has developed a prototype GFS system, but problems exist in the coverage of the general government. In particular, data for provincial governments are unavailable and ongoing audits of state enterprises have yet to be completed. The authorities started collecting disbursement information on donors' grants in 2006. The introduction of the Commonwealth Secretariat Debt Recording and Management System (CS-DRMS) database in the CBSI and MOF in March 2005 has improved the quality of official debt data, but coordination problems remain. The MOF does not report annual or subannual GFSM 2001-based data for the Government Finance Statistics Yearbook (GFSY) and the International Financial Statistics (IFS), respectively.

\section{External Sector Statistics}

The CBSI estimates partial quarterly BOP statistics based on cash foreign exchange transactions, reported through the banking system, which are available with a three-month lag. These data are deficient in detail and coverage, and classification problems remain. An April 2008 PFTAC-TA mission found the Customs trade data lacking in accuracy, helped the CBSI carry out surveys, and introduced appropriate changes in methodology. As a result, the BOP data have been revised quite significantly.

\section{Remedial Measures}

The NSO is gradually resuming data collection and publication responsibilities, but its effectiveness continues to be hampered by weak technological skills among its staff and low survey response rates. The authorities have agreed on an action plan with the recent PFTACTA mission to implement measures to effectively move the responsibility for national accounts statistics back to the NSO in 2009. 
Looking forward, the authorities need to focus on a number of statistical issues identified by various PFTAC-TA missions, including: (i) ensuring that compilation methodologies are applied consistently for GDP and BOP data; and (ii) collecting prices for additional items in the CPI, particularly on diesel fuel and telecommunications products. In the area of the BOP, there is a need to: (i) increase the response rate to enterprise surveys to reduce reliance on FET records; (ii) investigate alternative data to supplement FET data, including the use of official transfers data from the government's financial accounts; and (iii) review the Customs merchandise trade data. 
TABLE VII. 1. SOLOMON ISLANDS-COMMON INDICATORS REQUIRED FOR SURVEILLANCE (As of August 20, 2008)

\begin{tabular}{|c|c|c|c|c|c|}
\hline & $\begin{array}{l}\text { Date of latest } \\
\text { observation }\end{array}$ & $\begin{array}{l}\text { Date } \\
\text { received }^{10}\end{array}$ & $\begin{array}{l}\text { Frequency } \\
\text { of Data }^{11}\end{array}$ & $\begin{array}{l}\text { Frequency } \\
\text { of } \\
\text { Reporting }^{11}\end{array}$ & $\begin{array}{l}\text { Frequency of } \\
\text { publication }^{11}\end{array}$ \\
\hline Exchange Rates & July 2008 & July 2008 & $\mathrm{D}$ & M & M \\
\hline $\begin{array}{l}\text { International Reserve Assets and Reserve } \\
\text { Liabilities of the Monetary Authorities }{ }^{1}\end{array}$ & June 2008 & Aug. 2008 & W & M & M \\
\hline Reserve/Base Money & May 2008 & July 2008 & M & M & M \\
\hline Broad Money & May 2008 & July 2008 & M & M & M \\
\hline Central Bank Balance Sheet & May 2008 & July 2008 & M & M & M \\
\hline $\begin{array}{l}\text { Consolidated Balance Sheet of the Banking } \\
\text { System }\end{array}$ & May 2008 & July 2008 & M & M & M \\
\hline Interest Rates ${ }^{2}$ & June 2008 & June 2008 & W & M & M \\
\hline Consumer Price Index & June 2008 & July 2008 & M & M & M \\
\hline $\begin{array}{l}\text { Revenue, Expenditure, Balance and } \\
\text { Composition of Financing }{ }^{3} \text {-Central } \\
\text { Government }\end{array}$ & $\begin{array}{l}\text { December } \\
2007\end{array}$ & April 2008 & $A$ & $A$ & A \\
\hline $\begin{array}{l}\text { Revenue, Expenditure, Balance and } \\
\text { Composition of Financing }{ }^{3} \text {-General } \\
\text { Government }\end{array}$ & NA & NA & NA & NA & NA \\
\hline $\begin{array}{l}\text { Stocks of Central Government and Central } \\
\text { Government-Guaranteed Debt }\end{array}$ & $\begin{array}{l}\text { December } \\
2007\end{array}$ & April 2008 & $A$ & $A$ & A \\
\hline External Current Account Balance ${ }^{6}$ & May 2008 & Aug. 2008 & Q & Q & Q \\
\hline Exports and Imports of Goods and Services ${ }^{6}$ & $\begin{array}{l}\text { December } \\
2007\end{array}$ & April 2008 & Q & Q & Q \\
\hline $\mathrm{GDP}^{7}$ & $\begin{array}{l}\text { December } \\
2007\end{array}$ & April 2008 & A & A & A \\
\hline Gross External Debt ${ }^{8}$ & $\begin{array}{l}\text { December } \\
2007\end{array}$ & April 2008 & $A$ & $A$ & $\begin{array}{l}\text { Upon } \\
\text { Request }\end{array}$ \\
\hline International Investment Position ${ }^{9}$ & NA & NA & NA & NA & NA \\
\hline
\end{tabular}

${ }^{1}$ Includes reserve assets pledged or otherwise encumbered as well as net derivative positions.

${ }^{2}$ Both market-based and officially-determined, including discount rates, money market rates, rates on Treasury bills, notes and bonds.

${ }^{3}$ Foreign, domestic bank, and domestic non-bank financing.

${ }^{4}$ The general government consists of the central government (budgetary funds, extra budgetary funds, and social security funds) and state and local governments.

${ }^{5}$ Including currency and maturity composition.

${ }^{6}$ Detailed BOP data derived from FET through the banking system and trade data from the Customs and Excise Division are available on a quarterly basis with a 3-month and 5-month lag, respectively.

${ }^{7}$ The most recent official data are for 1994, but the central bank has produced real production estimates through 2006.

${ }^{8}$ Data on private sector debt is not available.

${ }^{9}$ Includes external gross financial asset and liability positions vis a vis nonresidents.

${ }^{10}$ Includes data received following specific requests by Fund staff.

${ }^{11}$ Daily (D), Weekly (W), Monthly (M), Quarterly (Q), Annually (A); and Not Available (NA). 
Public Information Notice (PIN) No. 08/139

FOR IMMEDIATE RELEASE

International Monetary Fund

October 2008

$70019^{\text {th }}$ Street, NW

Washington, D. C. 20431 USA

\section{IMF Executive Board Concludes 2008 Article IV Consultation with the Solomon Islands}

On October 20, 2008, the Executive Board of the International Monetary Fund (IMF) concluded the Article IV consultation with the Solomon Islands. ${ }^{1}$

\section{Background}

Economic performance has been robust since peace and order was restored in 2003 largely on account of unsustainable logging and aid flows. Real GDP growth averaged 7 percent in the past five years and macroeconomic stability has been maintained. Despite this stellar growth performance-unprecedented since the country's independence in 1978-the Solomon Islands remains the poorest in the region. The anticipated sharp decline in logging and aid flows poses serious risks to medium-term fiscal and external sustainability. Moreover, there have been frequent changes in government which has slowed the pace of critical structural reforms to enhance nonlogging sources of growth.

In 2007, growth accelerated to 10.3 percent, driven mainly by logging and other emerging sectors (palm oil and services), but is expected to decline to 7 percent in 2008 as logging activity starts to fall. Inflation rose to about 16 percent (3-month moving average) in June from 10 percent in end-2007, but will likely moderate towards the end of the year as commodity prices stabilize and recent monetary tightening measures take hold. Reserve levels remained comfortable at end-2007, but the current account is

\footnotetext{
${ }^{1}$ Under Article IV of the IMF's Articles of Agreement, the IMF holds bilateral discussions with members, usually every year. A staff team visits the country, collects economic and financial information, and discusses with officials the country's economic developments and policies. On return to headquarters, the staff prepares a report, which forms the basis for discussion by the Executive Board. At the conclusion of the discussion, the Managing Director, as Chairman of the Board, summarizes the views of Executive Directors, and this summary is transmitted to the country's authorities.
} 
projected to widen in $\mathbf{2 0 0 8}$ due to the deterioration in the terms of trade. Nevertheless, reserves are likely to remain adequate given continued strong donor inflows, logging export receipts, and FDI inflows from the mining sector.

After several years of surpluses, the fiscal balance swung to a small deficit in 2007. Strong revenue performance was overtaken by spending excesses on wages and goods and services. In 2008, the budget will likely remain expansionary, with a supplementary budget of nearly 6 percent of GDP passed by parliament recently. This calls for further monetary tightening to help prevent inflation from becoming entrenched.

Medium-term challenges from declining logging activity and aid flows are daunting and require accelerating critical reforms. Measures to strengthen the government's fiscal position remains slow, although some progress has been made. In particular, a mediumterm fiscal framework has been drafted and the determined price of logs (which is used for the calculation of logging taxes) has been raised in May 2008. The expected decline in logging revenue calls for serious efforts to broaden the revenue base, rationalize fiscal spending, and strengthen the finances of state-owned enterprises to place the fiscal sector on a more sustainable footing. The debt situation has improved recently, but remains highly sensitive to a decline in export and GDP growth. Meanwhile, external sustainability relies solely on the coming on stream of gold production in 2010, after several delays in commencement owing inter alia to land ownership issues.

Limited progress has been made to stimulate sustained non-logging sources of growth. The country remains beset with poor infrastructure, land ownership issues, a shortage of skilled labor, and unreliable and costly basic services. In addition, weak governance remains a serious concern. Nevertheless, some progress has been made in improving infrastructure with the help of ADB and enhancing competition in the airline industry. Other measures are also in the pipeline, including a draft Tribal Land Bill, strengthening the management of the state-owned electricity company, further improvements in infrastructure, and enhancing competition in the telecommunications sector.

\section{Executive Board Assessment}

Executive Directors welcomed the Solomon Islands' continued strong economic growth, driven mainly by logging activity, but also by a pickup in non-logging activity. However, Directors noted that inflation has risen as a result of fuel and food price shocks, rapid private sector credit growth, and an expansionary fiscal stance. Debt indicators are declining but remain high, and the current account is projected to deteriorate in the near term because of the terms of trade shock. Over the medium term, the economic outlook hinges critically on developing non-logging sources of growth and exports to offset the expected decline in logging activity.

Directors therefore highlighted the urgency of tightening fiscal and monetary policies and forcefully implementing structural reforms to maintain macroeconomic stability, safeguard fiscal and external sustainability, and accelerate growth in the non-logging sectors. In particular, they stressed the importance of ensuring that gold mining operations start as expected in 2010 , to alleviate possible pressure on the balance of 
payments arising from declining log exports. Directors welcomed the authorities' commitment not to undertake new external borrowing.

Directors commended the government's adoption of a medium-term fiscal strategy to achieve a balanced budget, by both boosting tax revenue and reducing non-priority expenditure. Efforts to improve tax administration and widen the tax base would be crucial. Raising the reference price of logs to reflect international market prices and narrowing ad hoc tax exemptions could make essential contributions. Directors stressed the need to rationalize civil service employment, contain the government wage bill, and enhance the efficiency of state-owned enterprises. Better expenditure-control procedures would keep spending within budgeted levels and foster enhanced budgetary transparency and accountability.

Directors observed that, while the recent decline in commodity prices would ease inflationary pressures, further tightening of monetary policy would prevent inflation from becoming entrenched. They supported efforts by the central bank to rein in excess liquidity. Directors recommended that the central bank seek to develop financial markets further and make greater use of interest rate mechanisms of monetary control. To avoid placing undue burden on monetary policy, fiscal policy needs to play a supportive role, especially in the near term.

Directors agreed that the real effective exchange rate appears to be broadly in line with medium-term economic fundamentals. They also considered that the current exchange rate peg to a basket of currencies has served the country well. Nonetheless, greater exchange rate flexibility could help encourage export diversification, easing the impact of the expected decline in log exports.

Directors noted that the turbulence in global financial markets has not had a noticeable impact on the financial sector in the Solomon Islands. Banks are profitable, liquid, and well-capitalized, and non-performing loans are low. Nevertheless, banks remain vulnerable to slower growth especially in the logging sector. Directors therefore advised the central bank to continue to monitor banking developments closely to ensure that asset quality remains sound.

Directors commended the various structural reforms being implemented to enhance the business climate and stimulate the growth of non-logging sectors. They attached high priority to efforts to improve the infrastructure, allow competition in the airline and telecommunications industries, address land ownership issues, and lower the cost of doing business. Directors strongly encouraged the authorities to move quickly on these reforms.

Directors welcomed the authorities' continuing efforts to improve the quality and timeliness of macroeconomic data. They stressed the need to allocate sufficient resources, ensure adequate staff training, and benefit from continued Fund technical assistance. 
Public Information Notices (PINs) form part of the IMF's efforts to promote transparency of the IMF's views and analysis of economic developments and policies. With the consent of the country (or countries) concerned, PINs are issued after Executive Board discussions of Article IV consultations with member countries, of its surveillance of developments at the regional level, of post-program monitoring, and of ex post assessments of member countries with longer-term program engagements. PINs are also issued after Executive Board discussions of general policy matters, unless otherwise decided by the Executive Board in a particular case. 
Solomon Islands: Selected Economic Indicators, 2003-09

$\begin{array}{ll}\text { Nominal GDP (2007): } & \text { US } \$ 388 \text { million } \\ \text { Population (2007): } & 508,420 \\ \text { GDP per capita (2007): } & \text { US } \$ 764 \\ \text { Quota: } & \text { SDR } 10.4 \text { million }\end{array}$

\begin{tabular}{|c|c|c|c|c|c|c|c|}
\hline & \multirow[t]{2}{*}{2003} & \multirow[t]{2}{*}{2004} & \multirow[t]{2}{*}{2005} & \multirow[t]{2}{*}{2006} & \multirow{2}{*}{$\begin{array}{r}2007 \\
\text { Est. }\end{array}$} & 2008 & 2009 \\
\hline & & & & & & \multicolumn{2}{|c|}{ Proj. } \\
\hline \multicolumn{8}{|l|}{ Growth and prices (percentage change) } \\
\hline Real GDP & 6.5 & 8.0 & 5.0 & 6.1 & 10.3 & 7.3 & 4.0 \\
\hline $\mathrm{CPI}$ (period average) & 10.0 & 6.9 & 7.4 & 11.2 & 7.7 & 15.1 & 8.8 \\
\hline $\mathrm{CPI}$ (end of period) & 3.7 & 7.6 & 8.6 & 9.9 & 10.9 & 14.6 & 6.5 \\
\hline Per capita GDP (in US\$) & 503 & 560 & 609 & 676 & 764 & 905 & 966 \\
\hline \multicolumn{8}{|l|}{ Central government operations (percent of GDP) } \\
\hline Total revenue & 39.2 & 48.1 & 66.2 & 64.7 & 69.0 & 61.6 & 60.7 \\
\hline Recurrent revenue & 21.2 & 26.3 & 29.7 & 32.3 & 36.8 & 33.0 & 32.4 \\
\hline Grants & 18.0 & 21.8 & 36.6 & 32.5 & 32.2 & 28.6 & 28.3 \\
\hline Total expenditure $1 /$ & 37.4 & 39.1 & 63.6 & 63.0 & 70.4 & 65.2 & 59.3 \\
\hline Recurrent expenditure & 21.9 & 21.6 & 26.7 & 30.7 & 33.0 & 35.3 & 30.1 \\
\hline Development expenditure & 15.5 & 17.4 & 36.9 & 32.3 & 37.5 & 29.8 & 29.2 \\
\hline Overall balance $2 /$ & 1.8 & 9.0 & 2.6 & 1.7 & -1.5 & -3.6 & 1.4 \\
\hline Foreign financing (net) & 0.8 & 0.0 & 4.7 & 2.1 & 3.2 & -1.0 & -1.7 \\
\hline Domestic financing (net) & -9.3 & -6.7 & -2.3 & -1.8 & -1.1 & 4.2 & 0.1 \\
\hline Other & 9.9 & -2.3 & -3.0 & -0.3 & -0.5 & 0.3 & 0.1 \\
\hline Discrepancy (neg. are net expenditures) & -3.3 & 0.0 & -2.0 & 1.8 & 0.1 & 0.0 & 0.0 \\
\hline Central government debt (percent of GDP) 3/ & 120.4 & 88.6 & 72.6 & 63.5 & 52.3 & 41.9 & 36.1 \\
\hline Domestic & 51.5 & 30.1 & 24.0 & 18.1 & 14.4 & 11.6 & 10.0 \\
\hline External & 68.9 & 58.4 & 48.6 & 45.4 & 37.9 & 30.3 & 26.1 \\
\hline External debt (in US\$ millions, end of period) & 157.7 & 153.1 & 142.6 & 151.7 & 147.3 & 143.1 & 135.5 \\
\hline External debt service to exports of GNFS (accrual basis) & 5.0 & 3.5 & 5.3 & 2.5 & 5.2 & 2.9 & 4.2 \\
\hline \multicolumn{8}{|l|}{ Monetary and credit (percentage change, end-year data) } \\
\hline M3 & 25.4 & 19.5 & 38.9 & 26.4 & 24.0 & 16.1 & 14.6 \\
\hline Base Money & 26.5 & 75.7 & 20.0 & 8.1 & -2.0 & -5.0 & 11.6 \\
\hline Interest rate (3-month t/bill rate, average) & 5.8 & 6.0 & 4.5 & 3.4 & 3.2 & $\ldots$ & $\ldots$ \\
\hline \multicolumn{8}{|l|}{ Balance of payments (US\$ millions, unless otherwise indicated) } \\
\hline Current account & 20.9 & 61.5 & -28.7 & -18.8 & -10.8 & -32.2 & -49.9 \\
\hline (Percent of GDP) & 9.1 & 23.5 & -9.8 & -5.6 & -2.8 & -6.8 & -9.6 \\
\hline Overall balance (accrual) & 18.8 & 43.4 & 16.0 & 9.4 & 17.0 & -19.3 & -8.8 \\
\hline Gross official reserves (US\$ millions, end of period) & 36.3 & 79.5 & 94.6 & 103.5 & 119.8 & 100.5 & 91.7 \\
\hline (in months of projected imports of GNFS) & 4.0 & 5.5 & 5.3 & 4.2 & 4.1 & 3.1 & 2.8 \\
\hline Exchange rate (SI\$/US\$, end of period) & 7.49 & 7.51 & 7.58 & 7.62 & 7.66 & $\cdots$ & $\ldots$ \\
\hline Real effective exchange rate (period average, $2000=100$ ) & 78.5 & 77.1 & 79.5 & 85.5 & 84.7 & $\ldots$ & $\ldots$ \\
\hline Nominal effective exchange rate (period average, $2000=100$ ) & 64.4 & 60.3 & 59.1 & 58.5 & 55.0 & $\ldots$ & $\ldots$ \\
\hline
\end{tabular}

Sources: Data provided by the authorities; and Fund staff estimates and projections.

$1 /$ Expenditures are presented on an accrual basis.

2/ Calculated from above-the-line data.

$3 /$ Includes arrears. 